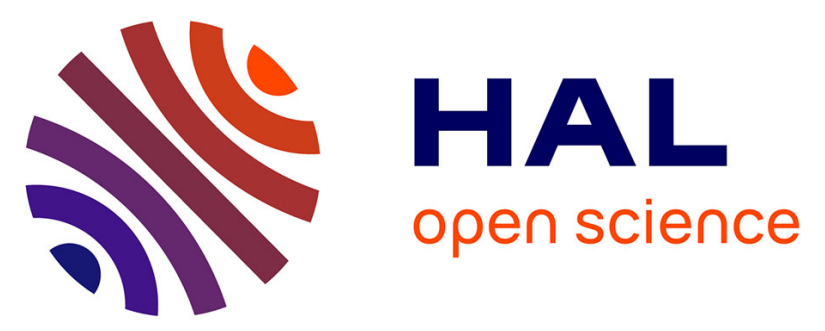

\title{
Influence of rainfalls on heat and steam fluxes of fumarolic zones: Six months records along the Ty fault (Soufrière of Guadeloupe, Lesser Antilles)
}

\author{
Damien Gaudin, Anthony Finizola, Eric Delcher, François Di Beauducel, \\ Pascal Allemand, Christophe Delacourt, Élodie Brothelande, Aline Peltier, \\ Fabio Di Gangi
}

\section{To cite this version:}

Damien Gaudin, Anthony Finizola, Eric Delcher, François Di Beauducel, Pascal Allemand, et al.. Influence of rainfalls on heat and steam fluxes of fumarolic zones: Six months records along the Ty fault (Soufrière of Guadeloupe, Lesser Antilles). Journal of Volcanology and Geothermal Research, 2015, 302, pp.273-285. 10.1016/j.jvolgeores.2015.06.015 . hal-01391252

\section{HAL Id: hal-01391252 \\ https://hal.univ-reunion.fr/hal-01391252}

Submitted on 5 Nov 2016

HAL is a multi-disciplinary open access archive for the deposit and dissemination of scientific research documents, whether they are published or not. The documents may come from teaching and research institutions in France or abroad, or from public or private research centers.
L'archive ouverte pluridisciplinaire HAL, est destinée au dépôt et à la diffusion de documents scientifiques de niveau recherche, publiés ou non, émanant des établissements d'enseignement et de recherche français ou étrangers, des laboratoires publics ou privés. 


\title{
Influence of rainfalls on heat and steam fluxes of fumarolic zones: Six months records along the Ty fault (Soufrière of Guadeloupe, Lesser Antilles)
}

\author{
Damien Gaudin a,b,*, Anthony Finizola ${ }^{\mathrm{c}}$, Eric Delcher ${ }^{\mathrm{c}}$, François Beauducel ${ }^{\mathrm{d}}$, Pascal Allemand ${ }^{\mathrm{e}}$, \\ Christophe Delacourt ${ }^{\mathrm{b}}$, Elodie Brothelande ${ }^{\mathrm{f}}$, Aline Peltier ${ }^{\mathrm{g}}$, Fabio Di Gangi ${ }^{\mathrm{h}}$ \\ a Istituto Nazionale di Geofisica e Vulcanologia, sezione di Rome, Italy \\ b Laboratoire Domaines Océaniques, UMR 6538, Université de Bretagne Occidentale, IUEM, France \\ C Laboratoire GéoSciences Réunion, Université de la Réunion, Institut de Physique du Globe de Paris, Sorbonne Paris-Cité, CNRS UMR \\ 7154, Saint-Denis, La Réunion, France ${ }^{\mathrm{d}}$ Institut de Physique du Globe de Paris, Sorbonne Paris Cité, Univ. Paris Diderot, UMR 7154 \\ CNRS, France \\ e Université Lyon 1 et ENS de Lyon, CNRS, Laboratoire de Géologie de Lyon, UMR 5276, 2 rue Raphaël Dubois, 69622 Villeurbanne \\ Cedex, France \\ f Laboratoire Magmas et Volcans, Université Blaise Pascal, CNRS-IRD, OPGC, 5 rue Kessler, 63038 Clermont Ferrand, France \\ g Observatoire Volcanologique du Piton de la Fournaise, Institut de Physique du Globe de Paris, Sorbonne Paris Cité, Univ. Paris \\ Diderot, UMR 7154 CNRS, France \\ $\mathrm{h}$ Istituto Nazionale di Geofisica e Vulcanologia, sezione di Palermo, Italy
}

A B S T R A C T

Fumarolic zones are permeable areas where both steam and heat are expelled to the atmosphere. Surface fluxes and flows, which are representative of the intensity of the hydrothermal circulation in depth, can be monitored by thermometers, thermal infrared cameras, spectrometers, or condensers. However, the superficial activity of fumarolic zones can be modified by the meteorological conditions, in particular the rainfalls, which might result in erroneous estimations. From this perspective, we developed a set of physical equations to quantify the effects of rainfalls on the thermal behavior of fumarolic zones. Results were faced to continuous measurements achieved at the Ty fault fumarolic zone (La Soufrière volcano, Guadeloupe, Lesser Antilles) during six months in 2010, using six vertical series of thermometers measuring the heat transfer in the ground and one condenser measuring the rising steam flux. Results demonstrate that in the absence of rainfalls, heat and steam flux reach an equilibrium that is representa tive of the geothermal flux in depth. Conversely, after the rainfalls, the cooling of the ground provokes a deepening of the condensation level. The related soil temperature drop can be estimated by computing the heat required to warm the infiltrated water up to boiling temperature while the recovery rate is directly linked to the geothermal flux. Our observations allow defining in which conditions flux are at steady state, but also to build a first order numer ical model allowing estimating both the physical parameters of the ground (thermal conductivity, precipitation efficiency coefficient and surface flux constant) and the long term thermal behavior of the hydrothermal system. In particular, our results predict that the hydrothermal activity must vanish on the zones where the geothermal flux drops under a certain threshold $\left(60 \mathrm{~W} / \mathrm{m}^{2}\right.$ at La Soufrière). The existence of this limit may have strong implications for the precipitation rate of minerals and the possible reactivation of the fumarolic zones during vol canic crises.

\section{Introduction}

Hydrothermal systems are commonly associated with volcanoes, even dormant ones (Chiodini et al., 2001, 2005; Pribnow et al., 2003, Bennati et al., 2011). Water, either magmatic or meteoric, is heated by the magmatic body and steam can be generated (Harris and

\footnotetext{
* Corresponding author at: INGV Roma; Via di Vigna Murata, 605; 00143 Roma, Italy. Tel.: + 390651860638.

E-mail address: damien.gaudin@ingv.it (D. Gaudin).
}

Maciejewski, 2000; Aubert et al., 2008). Steam rises jointly with magmatic gases through the connected porosity and the fissures of the rock (Aubert et al., 2008) and can reach the surface. If the steam flux is high enough, fumaroles are emitted (Aubert, 1999). Otherwise, if the atmosphere significantly cools the surface, the steam mostly con densates inside the ground, and only a thermal anomaly is registered at the surface (Sekioka and Yuhara, 1974; Aubert, 1999; Gaudin et al., 2013).

Thus, the activity of a fumarolic area is representative of the intensity of the hydrothermal circulation in depth, and can be used to track 
changes in the volcanic activity (Ricci et al., submitted). A large variety of methods may be used to quantify the activity of diffuse degassing zones. Condensers allow direct measurements of the steam flux at a given depth, but require heavy infrastructures (Gerlach, 1980; Aubert, 1999). The electrical potential gradient generated by both the tempera ture gradient and the water circulation has also been used in many volcanoes (e.g. La Soufrière (Zlotnicki et al., 1992, 1994), Stromboli (Finizola et al., 2002) or La Fossa of Vulcano (Revil et al., 2008)), but the recorded signal relies on many parameters, and its conversion to a mass flux is not trivial (Corwin and Hoover, 1979). Finally, the activity of low flux hydrothermal zones can be monitored by estimating their heat fluxes. Close to the surface, most of the heat is carried by conduc tion and the fluxes can be estimated from the vertical temperature gradient (Aubert, 1999; Aubert et al., 2008). In some cases, the measured temperature at a single depth has been used as a proxy for the hydrothermal circulation intensity (e.g. Revil et al., 2008; Peltier et al., 2012), but no quantification of the fluxes have been done. Surface temperature anomaly measured by thermal infrared sensors can also be used to estimate the flux from the surface to the atmosphere (Sekioka and Yuhara, 1974). This method has been successfully applied to fumarolic zones of Satsuma Iwojima (Yuhara et al., 1978), Unzen (Yuhara et al., 1981) and La Soufrière (Gaudin et al., 2013).

However, two main limitations are associated with these measure ments. First, they require the estimation of physical parameters such as thermal conductivity and surface roughness, that can vary in time (Harris and Maciejewski, 2000; Finizola et al., 2010) and are usually associated with large uncertainties (Gaudin et al., 2013). Secondly, the measurements are usually carried out within the first tens of centime ters below the surface where the heat and gas fluxes are strongly affected by meteorological conditions, in particular rainfalls (Peltier et al., 2012).

Understanding and quantifying the functioning and the evolution of the shallowest part (up to $2 \mathrm{~m}$ ) of fumarolic zones under variable meteorological conditions have a two fold interest. First, it allows determining in which cases the measured fluxes are at steady state and representative of the deep geothermal fluxes. Secondly, the numer ical modeling of the time evolution of fumarolic zones may enable discriminating the effects of the rainfalls from the changes of the hydro thermal activity.

The goal of this study is thus to define the main equations allowing a first order modeling of the thermal behavior of the ground/atmosphere interface of fumarolic zones subject to variable rainfalls. Our physical model is faced to field measurements achieved at the "Ty Fault fumarolic zone" (La Soufrière volcano, Guadeloupe, Lesser Antilles) for 6 months in 2010, when six vertical sets of thermometers and one experimental condenser were used to estimate the temperature and the steam fluxes.

\section{Regional settings}

La Soufrière volcano $\left(16^{\circ} 02^{\prime} \mathrm{N}, 61^{\circ} 39^{\prime} \mathrm{W}, 1467 \mathrm{~m}\right.$ asl. $)$ is a part of the 200 ky old volcanic complex Grande Découverte, located on the inner Lesser Antilles subduction arc over an extension tectonic structure parallel to the arc (N0 to $\mathrm{N} 160^{\circ} \mathrm{E}$ ), called Ty fault. This $\sim 6 \mathrm{~km}$ long normal active dips steeply eastward $\left(\sim 75^{\circ}\right)$ and is associated with displacements up to $10 \mathrm{~m}$ (Feuillet et al., 2002). The Soufrière lava dome, $900 \mathrm{~m}$ wide and $300 \mathrm{~m}$ high, was extruded at the end of the last magmatic eruption in 1530 A.D. (Boudon et al., 2008). Since then, at least six phreatic eruption phases took place, all of them affecting only high permeability zones, i.e. the fractures and vent areas of the dome (Feuillard et al., 1983; Komorowski et al., 2005).

The Soufrière complex is marked by a persistent hydrothermal activity on and around the dome, producing fumaroles, thermal anomalies, and hot springs (Fig. 1) and linked to the volcano activity. During the most recent phreatic eruptions, fumaroles were very active (Zlotnicki et al., 1992), sometimes even appearing a few months before the paroxysm (Jolivet, 1958). Oppositely, the number and intensity of fumaroles decrease after the eruptions jointly to the global relaxation of the dome (Zlotnicki et al., 1992). For instance, after the last eruption in 1976 1977, the hydrothermal activity began to decrease. Since 1992, the fumarolic activity has been increasing again in particular on top of the dome (OVSG IPGP, 2014; Allard et al., 2014) which has been interpreted as the consequence of the emplacement of a new magma intrusion (Villemant et al., 2014).

In this study, we focus on a $\sim 100 \times 100$ m hydrothermal area located at the southern border of the dome, across the suspected junction between Ty fault and August 30, 1976 fault (Fig. 1). This zone, hereafter referred as the Ty fault fumarolic zone (TFFZ, Fig. 2), has been widely studied (e.g. Allard et al., 1998; Gaudin et al., 2013; Brothelande et al., 2014), as the only active zone aside from the top of the dome during the 1992 activity minimum. Fuma rolic activity increased jointly with the dome reactivation from 1992, but, since 2002, the activity at the TFFZ is weakening again (Brothelande et al., 2014; OVSG IPGP, 2014). At the time of the observation, the fumarolic zone was made of 5 separated patches with surface temperature anomalies and a few remaining fumaroles. A resistivity profile achieved in 2011 suggests that the permeable layer in which the circulation takes places is at least $30 \mathrm{~m}$ thick (Brothelande et al., 2014)

The chemical analysis of the gases sampled at $70 \mathrm{~cm}$ below the surface showed a composition dominated by water ( 93.3 to $97.4 \%$, Brombach et al., 2000), with temperatures close to vaporization temperature of the water (Gaudin et al., 2013). Closer to the surface, this ratio decreases due to the condensation of the steam (Allard et al., 2014). The dry phase of the gas is composed by $9095 \%$ of $\mathrm{CO}_{2}$ (Fig. 2), $45 \%$ of $\mathrm{H}_{2} \mathrm{~S}$, and variable amount of $\mathrm{H}_{2}, \mathrm{SO}_{2}$ and $\mathrm{CH}_{4}$, demon strating the magmatic origin of the gas (Allard et al., 1998; Brombach et al., 2000).

From a meteorological point of view, the Soufrière complex is affected by the rain bearing north east trades from the Atlantic Ocean (Chaperon et al., 1983; Opfergelt et al., 2012). A permanent meteorolog ical station, located at the top of the Soufrière dome, recorded between 2001 and 2013 an average of $4500 \mathrm{~mm}$ of rainfall per year. February and March are the driest months with a $30 \%$ rainfall decrease compared to the rest of the year (OVSG IPGP, 2010). On the slopes, yearly rainfalls reach 7000 to $8000 \mathrm{~mm}$ due to the Foehn effect (Opfergelt et al., 2012; Allemand et al., 2014).

\section{Physical model of a low-flux fumarolic zone}

Low flux fumarolic zones are made of a permeable material, allowing the steam fluxes upward. In depth, the observed tempera ture is constant and corresponds to the boiling temperature of water ( $97^{\circ} \mathrm{C}$ at approx. $1200 \mathrm{~m}$ of altitude), suggesting the existence of a purely convective layer that extends at TFFZ from at least $30 \mathrm{~m}$ (Brothelande et al., 2014) up to a few tenths of centimeters from the surface (Gaudin et al., 2013) where condensation takes place (Fig. 3).

In the scope of this paper, we model 1) the temperature, 2 ) the steam content and 3) the condensed water content in the shallowest $2 \mathrm{~m}$ in which short term variations of temperature and fluxes caused by changing weather can be observed. The considered do main includes both the condensation layer and the top of the purely convective zone (Fig. 3). The domain is thin enough to allow assuming that the physical parameters remain constant and the fluxes are vertical on the studied profiles (Aubert, 1999). In other words, we neglect the permeability contrasts that occur at larger scales and may lead to complex fluid and heat circulation. Since the base of the domain is locat ed in the purely convective layer, the steam, water and heat fluxes can be assumed to be constant and representative of the local geothermal activity. 


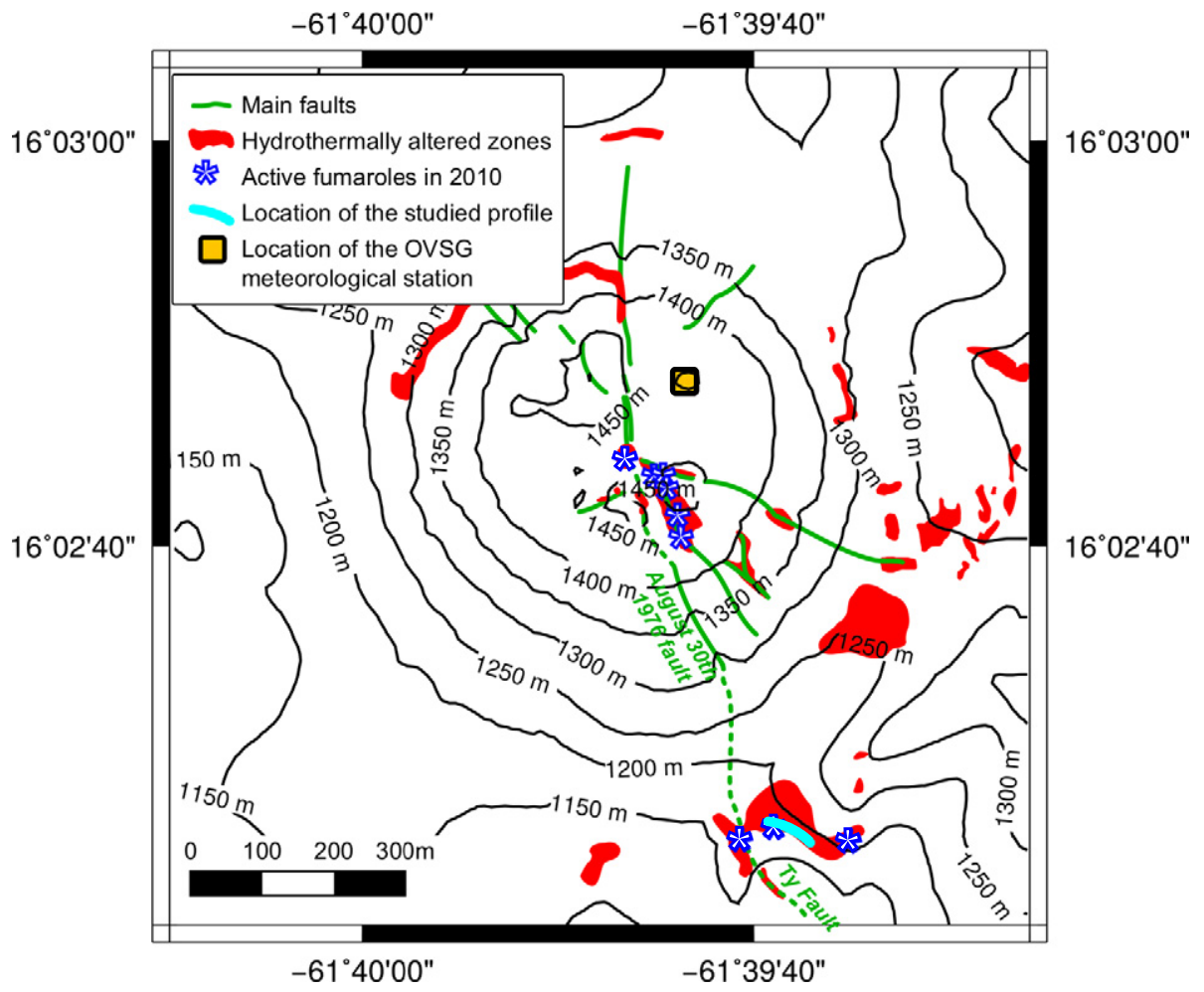

Fig. 1. Map of La Soufrière dome, reporting the main surface manifestations of the hydrothermal system in 2010 (after Beauducel, 2001; Nicollin et al., 2006).

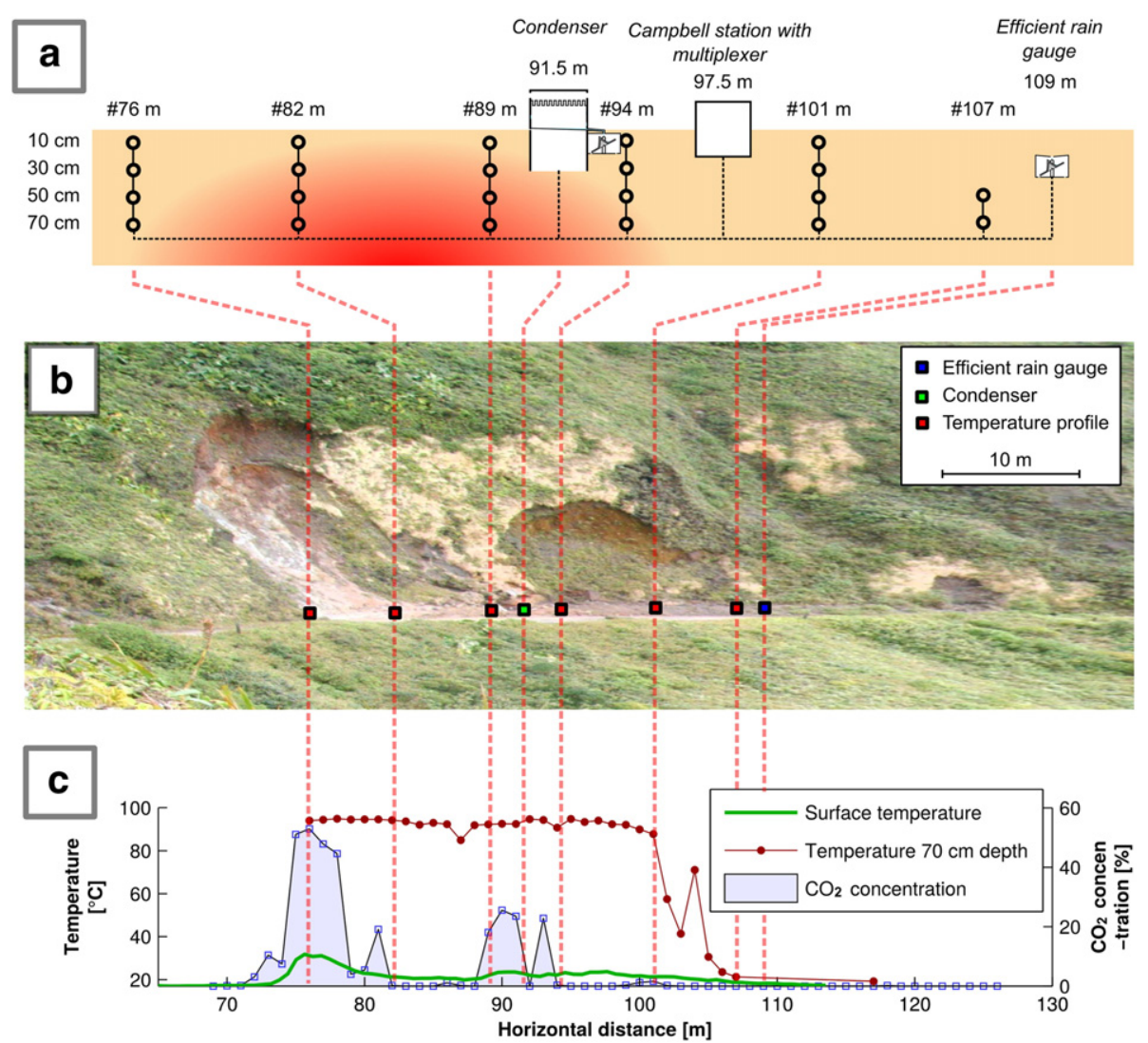

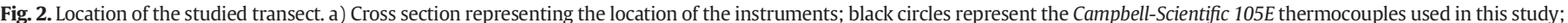

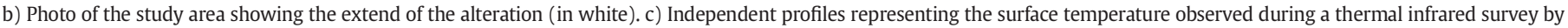

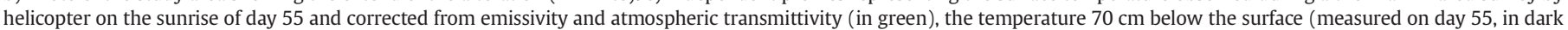
red). The $\mathrm{CO}_{2}$ concentration at a depth of $30 \mathrm{~cm}$, measured in 2008 (in purple) (Brothelande et al., 2014) demonstrates the magmatic origin of the gas. 


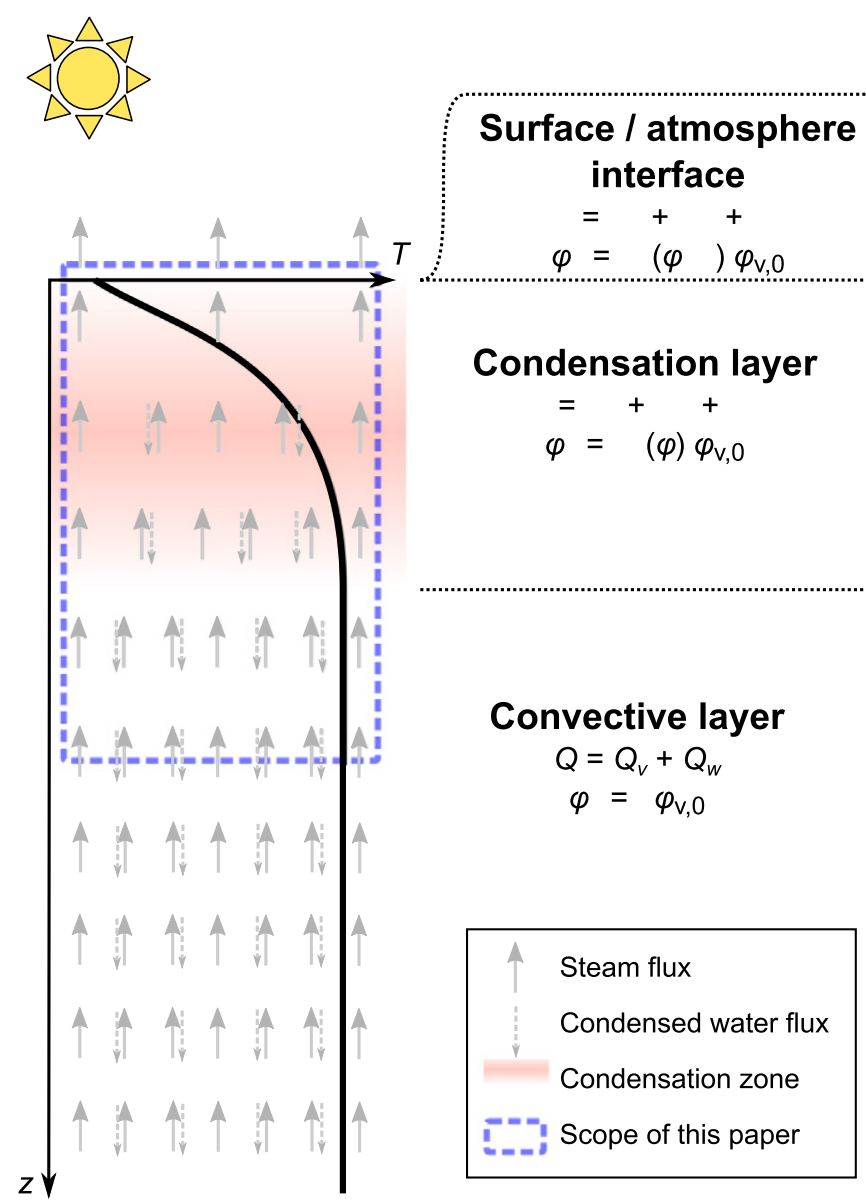

Fig. 3. Theoretical model of steam and water circulation in a low-flux fumarolic zone at equilibrium, after Aubert (1999). This paper focuses only on the condensation and the top of the purely convective layers (blue rectangle).

\subsection{Steam and heat flux at equilibrium}

\subsubsection{Steam flux}

The steam flow rate in the purely convective layer at the bottom of the considered domain is assumed constant with time and denoted $\varphi_{v, 0}\left(\right.$ in $\mathrm{kg} \mathrm{m}^{-2} \mathrm{~s}^{-1}$ ). Close to the surface, steam condensates due to the cooling of the host rock by the atmosphere. Indeed, the maximum steam content inside the rock pores, corresponding to the steam saturating pressure $p_{s a t}$, is linked to the temperature $T$ through the Rankine formula (Pruppacher and Klett, 2000):

$x \frac{p_{\text {sat }}}{p_{a t m}} \exp \left(\frac{5120}{T_{b o}}-\frac{5120}{T}\right)$

where $p_{a t m}$ is the atmospheric pressure and $T_{b o}$ is the boiling tempera ture of water. Assuming that the medium is physically homogeneous at the scale of the profile, the Darcy law (Lowell, 1991; Luna et al., 2002) states that the rise velocity of the steam should be constant in the column (Aubert, 1999; Gaudin et al., 2013). Since the steam flow is the product of the velocity and the water content inside the pores, at equilibrium $x$ also represents the ratio between the steam flow at a temperature $T\left(\varphi_{v}\right)$ and the one in the purely convective layer $\left(\varphi_{v, 0}\right)$.

Once condensed in the ground, the water flows downward together with the meteoric water down to the bottom layer where it escapes the study domain. As for steam, infiltration velocity is hereafter assumed to be vertical and constant. By convention, downward flows and fluxes will be denoted negatively.

\subsubsection{Heat flux}

The activity of a fumarolic zone can also be characterized by the geothermal flux (Sekioka and Yuhara, 1974; Aubert, 1999; Gaudin et al., 2013). Indeed, the steam flow can be converted into a heat flux $\left(Q_{v}\right.$, in $\left.\mathrm{W} \mathrm{m}^{-2}\right)$ corresponding to the energy that would be released in the atmosphere by the condensation and the cooling of the steam:

$Q_{v} \quad \varphi_{v}\left[L+c_{v}\left(T-T_{a t m}\right)\right]$

where $T$ and $T_{a t m}$ are respectively the steam and the atmospheric temper atures, $L$ is the enthalpy of vaporization of water $\left(2.35 \times 10^{6} \mathrm{~J} \mathrm{~kg}^{-1}\right)$ and $c_{v}$ is the heat capacity of steam $\left(1.99 \times 10^{3} \mathrm{~J} \mathrm{~kg}^{-1} \mathrm{~K}^{-1}\right)$.

Similarly, the heat brought by condensed water $\left(Q_{w}\right)$ can be written as follows:

$Q_{w} \quad \varphi_{w}\left[c_{w}\left(T-T_{a t m}\right)\right]$

where $c_{w}$ is the heat capacity of water $\left(4.18 \times 10^{3} \mathrm{~J} \mathrm{~kg}^{-1} \mathrm{~K}^{-1}\right)$. Note that, like $\varphi_{w}, Q_{w}$ is negative.

The cooling of the surface by the atmosphere produces a tempera ture gradient in the last centimeters of the ground, which generates a conductive heat flux $\left(Q_{c}\right)$ that can be computed through Fourier law (Turcotte and Schubert, 2002):

$Q_{c} \quad-k \mathrm{~d} T / \mathrm{d} z$

where $\mathrm{d} T / \mathrm{d} z$ is the temperature gradient ( $z$ being oriented upwards) and $k$ the conductivity of the medium, depending on the composition of the soil and on its porosity (Robertson, 1988; Brigaud and Vasseur, 1989). In the scope of this study, where only the two shallowest meters of the ground are modeled, the thermal conductivity will be assumed to be constant on each vertical profile.

The thermal anomaly at the surface generates a heat flux to the atmosphere. This flux can be split into a radiative flux, corresponding to the difference between the electromagnetic radiation received from the environment and those emitted, and a sensible flux, representing cooling by the atmospheric convection (Harris, 2013). While the first can be simply computed according to Stefan Boltzmann law (Harris, 2013), the latter depends on the atmosphere temperature and the wind velocity (Sekioka and Yuhara, 1974) that may be very variable due to the complex relief of the zone, and is thus associated with very large uncertainties (Gaudin et al., 2013; Harris, 2013). For simplification, we will assume in this study that the surface flux is proportional to the temperature contrast between the surface and the atmosphere:

$Q_{a} \quad h\left(T_{\text {surf }}-T_{a t m}\right)$

where $h$ is the surface flux coefficient $\left(\mathrm{W} \mathrm{m}^{-2} \mathrm{~K}^{-1}\right)$. This first order relationship can be obtained by linearizing the Stefan Boltzmann equation (assuming that the incoming electromagnetic radiation is directly linked to the atmosphere temperature) and neglecting the variations of wind velocity.

\subsubsection{Steady state profile}

At steady state, the sum of the heat fluxes is constant in the consid ered column (Fig. 3), allowing computation of equilibrium temperature and steam profiles depending on the geothermal flux and the physical parameters (Gaudin et al., 2013). Assuming that the condensed water mass flow is the opposite of the steam flow $\left(\varphi_{w}=-\varphi_{v}\right)$, we can use the Rankine ratio $x$ (Eq. (1)) to estimate the fraction of the heat flux carried by steam and water:

$\frac{Q_{v}+Q_{w}}{Q} \quad \frac{Q_{v}+Q_{w}}{Q_{v, 0}+Q_{w, 0}} \quad x \frac{\left[L+\left(c_{v}-c_{w}\right)\left(T-T_{a t m}\right)\right]}{\left[L+\left(c_{v}-c_{w}\right)\left(T_{b o}-T_{a t m}\right)\right]}$ 
The rest of the heat flux is carried by conduction, according to the thermal gradient (Eq. (4)). As a consequence, in the convective layer, the temperature gradient is null. Above, the condensation of steam provokes an increase of the proportion of heat carried by conduction and the temperature gradient. Below $40{ }^{\circ} \mathrm{C}$, the steam flux becomes negligible in the total heat flux, and the thermal gradient reaches a constant value (Fig. 3).

\subsection{Effects of the rainfall on the steam and temperature profiles}

Rainfalls disturb the thermal equilibrium in two ways. First, when hitting the ground, rainfalls decrease the surface temperature. Secondly, a fraction of the rainfall called "effective precipitations" penetrates into the soil. While it flows downwards, water is heated. Since the heat and steam fluxes are no longer at equilibrium, Eq. (6) cannot be used and flux estimations from a condenser or vertical temperature profile are no longer valid.

The time evolution of the temperature in the ground can be modeled using the heat balance:

$\rho_{r} C_{r} \frac{\mathrm{d} T}{\mathrm{~d} t} \quad \frac{\mathrm{d}\left(Q_{v}+Q_{w}+Q_{c}+Q_{a}\right)}{\mathrm{d} z}$

where $c_{r}$ is the heat capacity of the rock, about $800 \pm 300 \mathrm{~J} \mathrm{~kg}^{-1} \mathrm{~K}^{-1}$ (Hillel, 1982; Abu Hamdeh, 2003; Pielke, 2013). The density $\rho_{r}$ depends directly on the porosity of the rock; assuming $40 \%$ porosity, we estimate it to be around $1600 \mathrm{~kg} \mathrm{~m}^{-3}$ (Robertson, 1988; Brigaud and Vasseur, 1989). Finally, the temperature variations modify the saturating pressure of steam, according to Eq. (1).

\subsection{Numerical model of the fluxes}

The equations described above are used to build a numerical model in order to evaluate the evolution of a hydrothermal zone with variable meteorological conditions. The model is based on the calculation of the vertical profiles of 1 ) temperature, 2) steam content, and 3) water content (effective precipitations and condensed steam). Profiles are discretized in $1 \mathrm{~cm}$ high elements, up to a depth of $2 \mathrm{~m}$, ensuring that the base of the model of the profile remains in the purely convective layer. Profiles are updated for each $2 \mathrm{~s}$ time step, by computing succes sively 1 ) the steam and liquid water flows;2) the condensation of steam at the points where steam pressure exceed the saturating pressure (Eq. (1)); and 3) the temperature variation based on the energy balance for each cell (Eq. (7)). In high permeability media, we can assume that the upward velocity of steam and the downward velocity of water are high enough so that the characteristic penetration time is small with respect to the variations of meteorological conditions.

This model can be used to predict the long term evolution of a fumarolic zone. In addition, by comparing the predictions with the observations for different sets of parameters, we can determine the "best parameter estimate" for each dataset. Operatively, for every set of parameters, the RMS is computed as:

RMS $\sqrt{\frac{\sum\left(T_{o b s}-T_{\text {model }}\right)^{2}}{n}}$

where $n$ is the number of observations. The parameter estimation is improved iteratively.

\section{The experimental setup}

In order to face our theoretical model with field observations, we use the data of a permanent station on a transect located on the easternmost thermal anomaly of the TFFZ, including 50 thermometers,
33 self potential sensors, one condenser and one buried rain gauge. Operatively, a $60 \mathrm{~cm}$ wide and $80 \mathrm{~cm}$ deep trench has been dug and then filled back. We compacted the replaced material so that the final volume equals the replaced volume, so the porosity should not have changed. The trench was mainly located inside the thermal anomaly. Only the easternmost extremity is located near to cold temperature values (Fig. 2). The sensors are labeled according to the linear distance from the western limit of the whole fumarolic zone. For the scope of this study, only a part of the setup is used, represented in Fig. 2.

Vertical temperature profiles were monitored in six points with a series of four Campbell Scientific 105E thermocouples (coupled chromel constantan) located $70,50,30$, and $10 \mathrm{~cm}$ below the surface (only 70 and $50 \mathrm{~cm}$ for the vertical profile at \#107 $\mathrm{m}$ ). The instrumental precision of the measurements is $0.5{ }^{\circ} \mathrm{C}$, but, considering the strong thermal gradient (up to $100{ }^{\circ} \mathrm{C} / \mathrm{m}$ ), the uncertainties in the vertical positioning $\left( \pm 2 \mathrm{~cm}\right.$ ) can lead to systematic errors up to $2{ }^{\circ} \mathrm{C}$.

Between points 91 and 92, the steam flow was monitored by an experimental condenser (Fig. 4). The base of the instrument is open and lets the steam flow in at a depth of $30 \mathrm{~cm}$. The steam, condensed in the upper part of the box, is carried to a Campbell Scientific ARG1000 tipping bucket gauge, providing a measurement in millimeter of con densed steam per hour (Fig. 4).

The rainfall was measured by another Campbell Scientific ARG1000 tipping bucket gauge, with a $40 \mathrm{~cm}$ diameter funnel and a measuring step of $0.25 \mathrm{~mm}$. The device was buried $30 \mathrm{~cm}$ below the surface in order to measure only the effective precipitations, thus excluding the runoff and the evapotranspiration. In order to avoid condensa tion of steam that could affect the results, the gauge was set outside the thermal anomaly zone, at point $109 \mathrm{~m}$ (Fig. 2). However, it should be noticed that the permeability of the soil above the rain gauge might differ from the permeability of the thermal anomaly zone.

The data from the thermocouples and the tipping bucket gauges were hourly digitized by a Campbell Scientific AM25T multiplexer, and stored in a Campbell Scientific CR1000 data logger, including a NL115

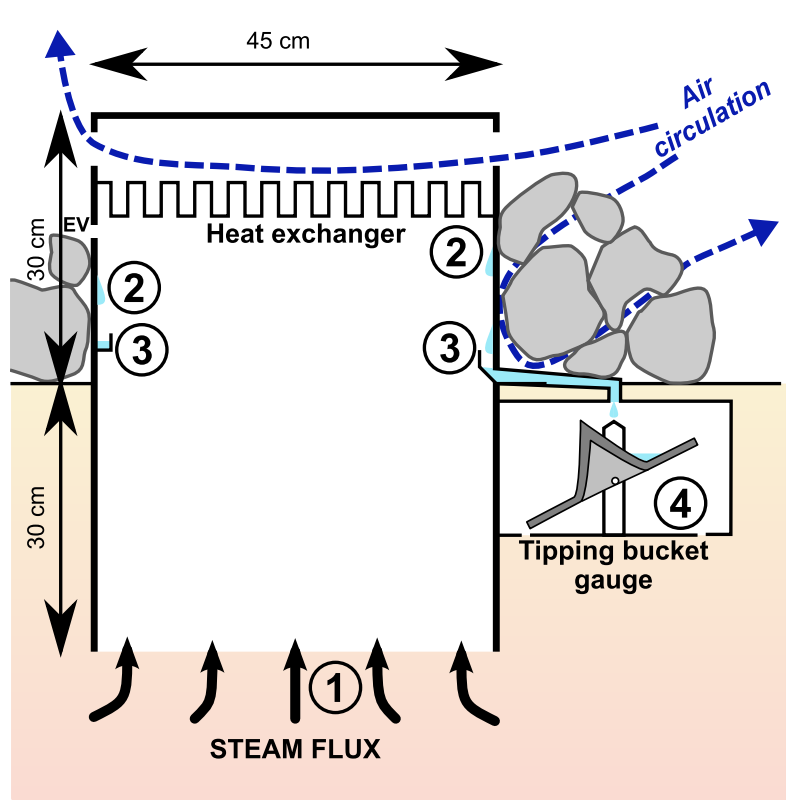

Fig. 4. Scheme of the condenser used in this study. The main unit consists of a $60 \times 45 \mathrm{~cm}$ box, whose bottom is opened, allowing the steam to flow inside (1). The upper part of the box is cooled by the atmosphere both by a heat exchanger and by the walls, which are protected from the sun by stones allowing air circulation. Steam is condensed on the walls (2), collected by a gutter (3) and brought to tipping bucket gauge where it is measured (4). A small exhaust valve (EV), located under the heat exchanger is used to equilibrate the pressure of the condenser and the atmosphere, while limiting the steam loss. 
module and powered by batteries and solar panels, allowing continuous measurements.

In this study, atmospheric temperatures $2 \mathrm{~m}$ above the surface were estimated from the thermometer of the OVSG meteorological station located on the top of La Soufrière dome (OVSG IPGP, 2010, Fig. 1). In order to account for the altitude difference between the summit and the study area, we increased the temperatures by $1.5^{\circ} \mathrm{C}$.

\section{Results}

The TFFZ station provided hourly measurements from 22/01/2010 to $23 / 07 / 2010$ (hereafter denoted days 22 and 203), when it was damaged by a landslide. Meteorological data show a clear distinction between a drier period between days 26 and 70 with only $4 \mathrm{~mm}$ of recorded effective rainfalls, and the wetter one with $1500 \mathrm{~mm}$ in 136 days (Fig. 5). During the experiment, 5 thermometers out of 22 experienced transient or technical problems, due to the extreme alteration conditions. The outliers, easily recognizable by their unrealis tic temperature, were discarded in order to provide high reliability measurements.

\subsection{Estimation of the fluxes at equilibrium}

During the drier period (days 26 70), the measured temperatures gradually reached a plateau. Main temperature variations occurred on a 24 hour timescale (Fig. 5), corresponding to the diurnal effects of insolation. The amplitude of the heat wave is divided by 2 to 6 every $20 \mathrm{~cm}$ and delayed by 3 to $5 \mathrm{~h}$. These values can be linked to the physical parameters of the soil (Turcotte and Schubert, 2002):

$\kappa \quad \frac{k}{\rho c} \frac{\omega}{2}\left(\frac{\Delta z}{\log \left(T_{2} / T_{1}\right)}\right)^{2} \quad \frac{1}{2 \omega}\left(\frac{\Delta z}{\Delta t}\right)^{2}$

where $\omega$ is the day angular frequency $\left(7.27 \times 10^{-5} \mathrm{rad} \cdot \mathrm{s}^{-1}\right), T_{2} / T_{1}$ and $\Delta t$ are respectively the ratio of the amplitude and the time delay of the heat wave between two sensors vertically spaced by $\Delta z$. From this equation, we estimate that the thermal conductivity of the ground lies between 0.5 and $2 \mathrm{~W} \mathrm{~m}^{-1} \mathrm{~K}^{-1}$. These values are in good accordance with the previous studies, considering the chemical composition of the soil, mainly andesite and smectite (Salaün et al., 2011) and its 40\%
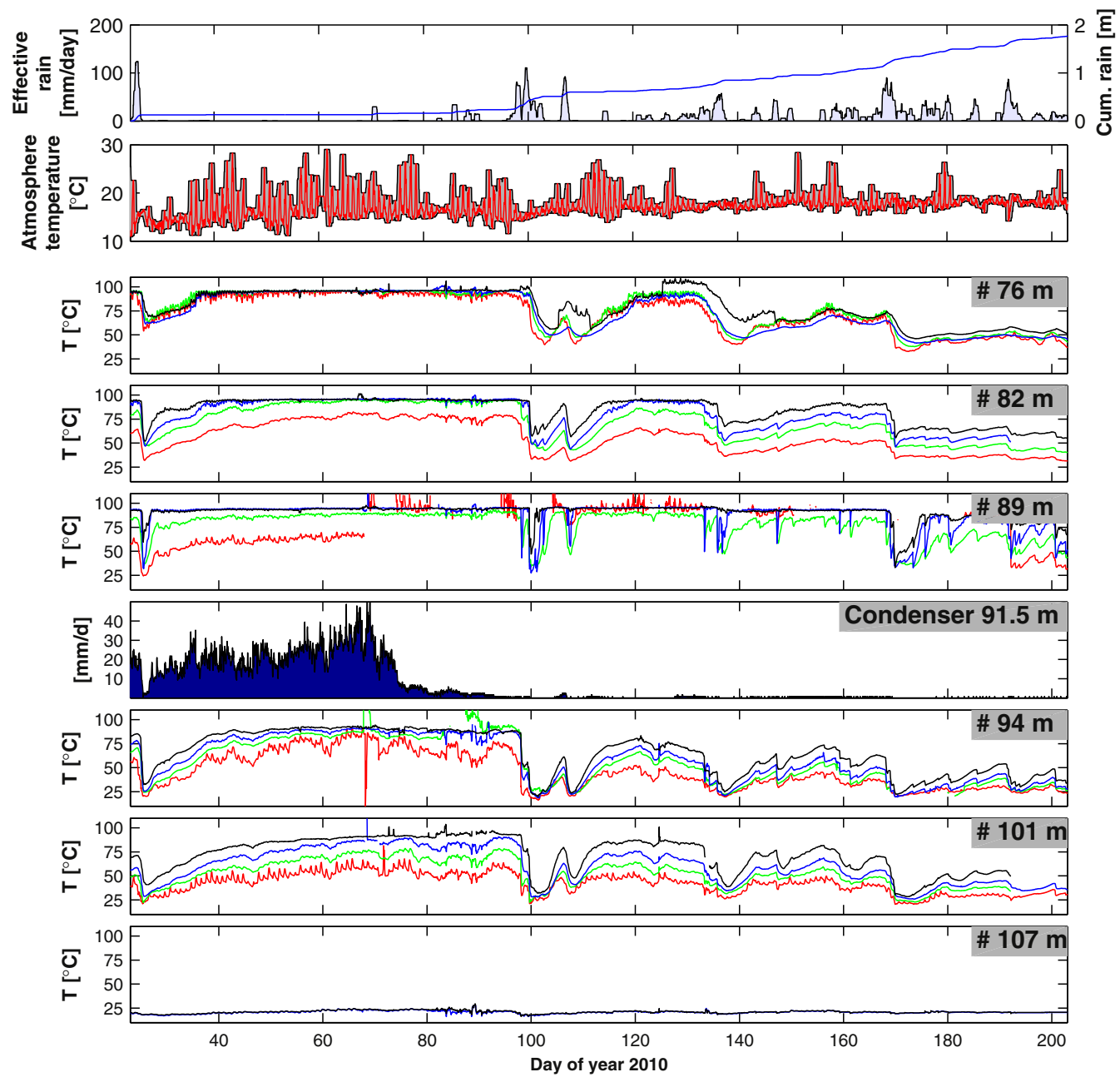

$10 \mathrm{~cm} \longrightarrow 50 \mathrm{~cm} \longrightarrow 70 \mathrm{~cm}$

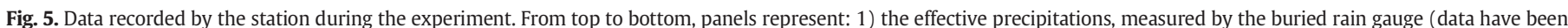

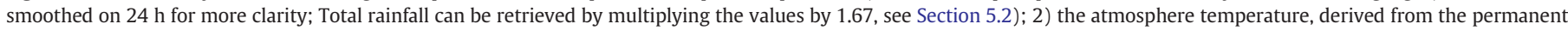

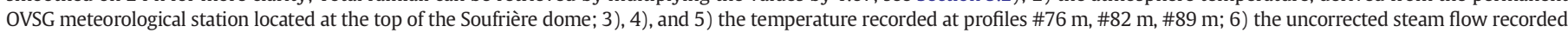
by the condenser; 7), 8) and 9) the temperature at profiles \#94 m, \#101 m and \#107 m. 


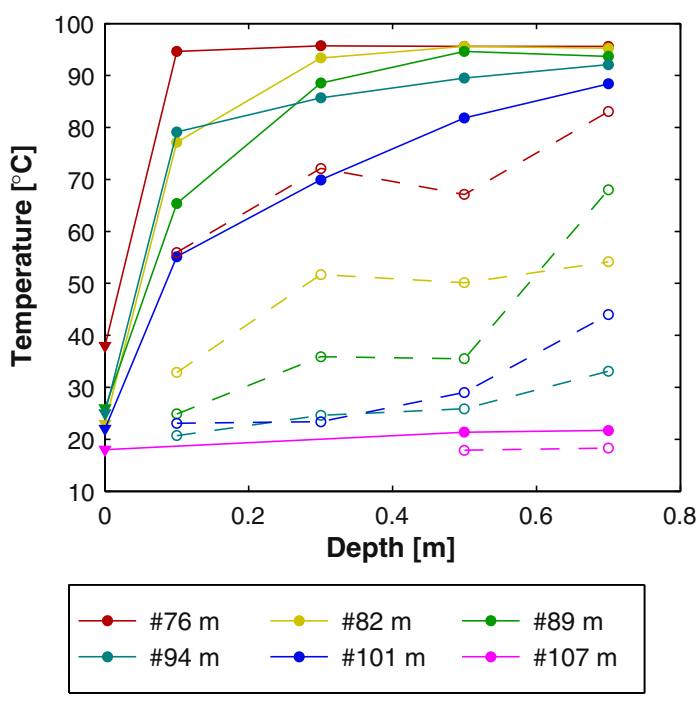

Fig. 6. Vertical temperature profiles measured on days 55 (steady state, solid line) and 26 (after the first rain fall event, dashed line). On day 55, surface temperatures were measured during a thermal infrared survey achieved by helicopter just before the sunrise and corrected from atmospheric transmissivity and surface emissivity. For each profile, the area between the two lines represents the loss of energy due to the rainfalls of day 25 .

porosity (Sheridan, 1970). For the rest of this study, the thermal heat waves are removed by averaging the data on $24 \mathrm{~h}$ and the thermal conductivity is set to $1 \mathrm{~W} \mathrm{~m}^{-1} \mathrm{~K}^{-1}$ (Robertson, 1988; Brigaud and Vasseur, 1989; Carson et al., 2005).

For each vertical set of thermometers, the equilibrium temperature profile (Fig. 6) and gradient (Table 1) can be computed (Aubert, 1999; Gaudin et al., 2013). The latter can be converted into heat flux from Eq. (4). On day 55, fluxes at a depth of $30 \mathrm{~cm}$ range from 110 to $401 \mathrm{~W} \mathrm{~m}^{-2}$ (Table 1), with higher values at the center west of the transect, in good qualitative agreement with the thermal infrared measurement of the surface temperature (Fig. 2b).

As for the temperature, the steam flow recorded by the experimental condenser shows clear diurnal variations (Fig. 5), that can be removed by a 24 hour averaging. During the dry period, the condenser recorded an average of $25 \mathrm{~mm}$ of condensed steam per day, which would represent a heat flux of $700 \mathrm{~W} \mathrm{~m}^{-2}$ according to Eq. (2). In fact, the base of the condenser, located $30 \mathrm{~cm}$ below surface level is maintained at atmospheric pressure, which causes an important suction effect. From Appendix A, we estimate that the condenser drains a surface 3.2 times larger than its base (Figs. A1 and A2). Thus, the actual geothermal flux $Q_{\nu}$ is approximately $215 \mathrm{~W} \mathrm{~m}^{-2}$ (8 $\mathrm{mm} /$ day). Although it does not take into account the conducted heat, this estimation is compatible with the retrieved heat fluxes from the neighbor temperature profiles.

\subsection{Rainfall events}

During the survey, a total of $1760 \mathrm{~mm}$ of effective precipitations were recorded by the buried rain gauge during the experiment. In the same time, the OVSG permanent station located at the summit of the volcanic dome measured $1740 \mathrm{~mm}$ of total rainfalls (OVSG IPGP, 2010). According to Opfergelt et al. (2012), the Foehn effect generates $60 \%$ more rainfalls on the south west slopes of the volcano than on the summit. Thus, we estimate the total rainfalls on the TFFZ to approx. $3000 \mathrm{~mm}$ during the study period, suggesting that the average precipi tation efficiency coefficient (ratio between the total and the effective precipitations) is about 0.60 at the location of the rain gauge.

During the drier period (days 26 70), short rainfall episodes were recorded. For instance, on day 25 , a significant rainfall occurred, with a total of $120 \mathrm{~mm}$ of water percolated in the buried rain gauge in $30 \mathrm{~h}$, which represents $200 \mathrm{~mm}$ of total precipitations. The temperature dwindled on all thermometers by 20 to $50{ }^{\circ} \mathrm{C}$ (Fig. 5). The effect on the whole layer can be assessed by computing the variation of the total energy stored per area unit in the first centimeters of the rock. Assuming that the temperature measured by each thermometer is representative of a $20 \mathrm{~cm}$ high layer centered on it, the total energy per unit area stored in the first $80 \mathrm{~cm}$ of the ground can be computed as follows:

$E \quad \sum_{i 1,4} \rho_{c} c_{c}\left(T_{i}-\overline{T_{a t m}}\right) \Delta z$

where $\overline{T_{a t m}}$ is the average temperature of the atmosphere during the observed period, $T_{i}$ is the temperature of the thermometer $i$ and $\Delta z$ is the vertical spacing between thermometers. The drop of the stored energy after the rainfall event ranges from 25 to $47 \mathrm{MJ} \mathrm{m}^{-2}$ (Fig. 7) depending on the profile. Note that the evolution of the temperature profiles (Fig. 6) suggests that the cooling is not limited to the first $80 \mathrm{~cm}$ (in particular for profiles 94 and 101), so that the energy drop estimations must be considered as lower bound loss of the whole column. The observed energy drops correspond to the energy required to heat 75 to $140 \mathrm{~mm}$ of rainfall from atmospheric to boiling tempera ture, demonstrating that almost all the efficient precipitation reach the convection level and meet the hydrothermal system.

After the rainfall, the equilibrium is progressively recovered (Figs. 5 and 7 ). The time needed to reach steady state ranges from 2.5 days (profile 89) to more than 10 days (profile 101). Just after the rainfall, the surface temperature being very close to the atmosphere tempera ture, the surface flux vanishes. As a consequence, the whole energy from the geothermal flux is used to heat the ground, and the recovery rate of the ground temperature can be used as an independent measure ment of the geothermal flux. Indeed, on vertical profile at \#89 m, the heating of $22 \mathrm{MJ} \mathrm{m}^{-2}$ day $^{-1}$ (Fig. 7) corresponds to a flux of $290 \mathrm{~W} \mathrm{~m}^{-2}$ while on vertical profile at $\# 101 \mathrm{~m}$, the geothermal flux should be at least $63 \mathrm{~W} \mathrm{~m}^{-2}$ (Table 1). This method has been tested on another individual rainfall that occurred on day 95. In most cases, the same range of values is retrieved (Table 1 ).

After day 70, rainfall occurs almost daily, with an average of $11 \mathrm{~mm}$ day $^{-1}$ of effective precipitations, which corresponds to approx imately $18 \mathrm{~mm}$ day $^{-1}$ of total rainfall. Regarding the evolution of the temperature in the ground, three main regimes can be distinguished (Fig. 5). (1) Highest fluxes (e.g. profile 89) are sufficient to allow the recovery of temperature equilibrium after each rainfall episode.

Table 1

Estimation of the heat flux from the geothermal gradient (columns 2-4) and the recovery rate after the rainfall events (columns 5-6).

\begin{tabular}{|c|c|c|c|c|c|}
\hline \multirow[t]{2}{*}{ Vertical $\mathrm{T}^{\circ} \mathrm{C}$ profile } & \multicolumn{3}{|c|}{$\begin{array}{l}\text { Estimation at a depth of } 30 \mathrm{~cm} \\
\text { (day 55) }\end{array}$} & \multirow{2}{*}{$\begin{array}{l}\begin{array}{l}\text { Estimation after day } 25 \mathrm{r} \\
\text { ainfall episode }\end{array} \\
Q \mathrm{Q}\end{array}$} & \multirow{2}{*}{$\begin{array}{l}\text { Estimation after day } 95 \\
\text { rainfall episode } \\
Q\end{array}$} \\
\hline & $Q_{c /} k$ & $\left(Q_{v}+Q_{w}\right) / Q$ & $Q / k$ & & \\
\hline \# 76 m & $4.8^{\circ} \mathrm{C} / \mathrm{m}$ & 0.988 & $401{ }^{\circ} \mathrm{C} \mathrm{m}^{1}$ & $25 \mathrm{~W} \mathrm{~m}^{2}$ & $115 \mathrm{~W} \mathrm{~m}^{2}$ \\
\hline \# $82 \mathrm{~m}$ & $50.2^{\circ} \mathrm{C} / \mathrm{m}$ & 0.861 & $362{ }^{\circ} \mathrm{C} \mathrm{m}^{1}$ & $105 \mathrm{~W} \mathrm{~m}^{2}$ & $96 \mathrm{~W} \mathrm{~m}^{2}$ \\
\hline \# 89 m & $82.7^{\circ} \mathrm{C} / \mathrm{m}$ & 0.707 & $282^{\circ} \mathrm{Cm}^{1}$ & $290 \mathrm{~W} \mathrm{~m}^{2}$ & $272 \mathrm{~W} \mathrm{~m}^{2}$ \\
\hline \# 94 m & $47.5^{\circ} \mathrm{C} / \mathrm{m}$ & 0.592 & $116^{\circ} \mathrm{Cm}^{1}$ & $140 \mathrm{~W} \mathrm{~m}^{2}$ & $121 \mathrm{~W} \mathrm{~m}^{2}$ \\
\hline \# 101 m & $74.1^{\circ} \mathrm{C} / \mathrm{m}$ & 0.328 & $110^{\circ} \mathrm{C} \mathrm{m}^{1}$ & $63 \mathrm{~W} \mathrm{~m}^{2}$ & $185 \mathrm{~W} \mathrm{~m}^{2}$ \\
\hline
\end{tabular}




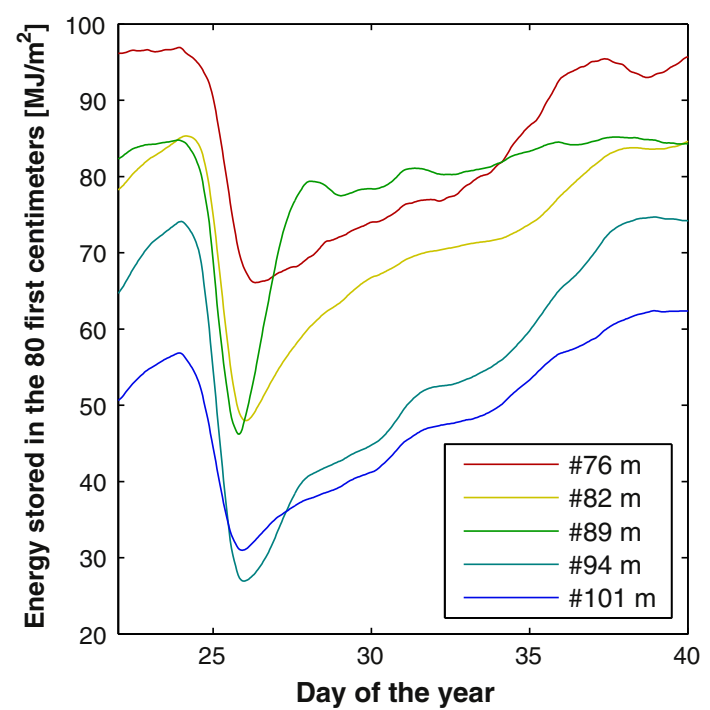

Fig. 7. Evolution of the energy stored in the first $80 \mathrm{~cm}$ of the soil, computed after Eq. (8). The rainfall event of day 25 generates an identical drop for all the profiles. Oppositely, the recovery time significantly depends on the geothermal flux.

(2) Conversely, at the edge of the thermal anomaly (e.g. profile 94 and $101)$ temperatures are kept very close to the atmospheric temperature. (3) Finally, an intermediate regime is represented by profiles 76 or 82.

As for the thermometers, rainfall episodes causes dramatically drops of the steam flow recorded in the condenser (Fig. 5). This drop can be associated with the cooling of the ground, which reduces the saturating pressure of steam, the condensation occurring at a deeper level. Accord ing to Eq. (1), the drop of the steam flow by a factor of 6 (from 25 to 4 $\mathrm{mm} /$ day) after day 25 could be explained by a temperature drop from $75{ }^{\circ} \mathrm{C}$ to $35{ }^{\circ} \mathrm{C}$, similar to observations of profile 89. Equilibrium is recovered after about 5 days, as for temperature profiles. Conversely, after day 95, almost no steam is recorded in the condenser, evidencing that the condensation zone remains below $30 \mathrm{~cm}$ (Fig. 3). According to our assumptions, the absence of condensation also suggests that the thermal gradient vanishes in the shallowest $30 \mathrm{~cm}$, or in other words, that the temperature at a 30 depth is maintained to atmospheric temperature. Surprisingly, most of the cooling occurs between days 70 and 95, while the small rainfall amount (4 mm/day of effective precipitations) does not affect significantly the neighbor temperature profiles, which suggests that the steam flow drop has been emphasized by another phenomenon.

\subsection{Parameter estimation}

In order to get the best estimates of the physical parameters of the fumarolic zone, we used the numerical model described in Section 3.3 to compute the set of parameters that best fits the observation of each profile (Eq. (8)). Since only four independent observations can be retrieved from the temperature observations (temperature gradient; surface temperature; temperature drop after a rainfall; equilibrium recovery rate), we focused this study on four parameters: 1 ) the geo thermal flux $\varphi ; 2$ ) the thermal conductivity $k ; 3$ ) the surface flux param eter $h$ (Eq. (5)); and 4) the precipitation efficiency coefficient. The other parameters, including the rock density and heat capacity, were set according to previous studies (Section 3.2). The study was focused on two time periods, from days 23 to 60 and 80 to 115 , in order to focus on single rainfall events.

The best parameter estimations are given in Table 2, while Fig. 8 depicts to which extent the parameters are constrained by the model. For the first rainfall episode (days 2360 ), geothermal fluxes are well constrained (Fig. 8), ranging from 128 to $256 \mathrm{~W} \mathrm{~m}^{-2}$ with a maximum value for the vertical profile \#89 $\mathrm{m}$ in very good agreement with the previous estimates (Table 1 ). For the second study period (days 80 115), the RMS errors are larger (Table 2). Indeed, the evolution of the fluxes is more difficult to estimate, because the rainfall evolution is more complex.

The precipitation efficiency coefficient ranges from 0.6 (same as the rainfall gauge) to 1 (no run off). The thermal conductivity ranges from 0.87 to $1.38 \mathrm{~W} \mathrm{~m}^{-1} \mathrm{~K}^{-1}$ for profiles 82 to 101 . These estimates are in very good agreement with the values computed with the amplitude decay and the time delay of the thermal wave (Section 5.1) and from previous studies (Robertson, 1988; Brigaud and Vasseur, 1989; Carson et al., 2005). Only profile 76 stands out, with an estimated conductivity of $4.92 \mathrm{~W} \mathrm{~m}^{-1} \mathrm{~K}^{-1}$. However, it must be noticed that no thermometer is in the conductive zone, which dramatically decrease the reliability of the estimation.

Unlike the values for thermal conductivity and precipitation efficien cy, the computed values of the surface flux coefficient $h$, ranging from 0 to $9 \mathrm{~W} \mathrm{~m}^{-2} \mathrm{~K}^{-1}$ are lower than the values predicted by the charts of Gaudin et al. (2013), $h$ being expected to be around $6 \mathrm{~W} \mathrm{~m}^{-2} \mathrm{~K}^{-1}$ for

Table 2

Best parameters estimates from numerical modeling. Figures in italic are associated with a very low reliability (see details in the text).

\begin{tabular}{|c|c|c|c|c|c|}
\hline \multicolumn{6}{|l|}{ Best fit parameters } \\
\hline Vertical $\mathrm{T}^{\circ} \mathrm{C}$ profile & Geothermal flux $Q$ & Precipitation efficiency coefficient & Thermal conductivity & Surface flux coefficient $h$ & Residuals (RMS error) \\
\hline \multicolumn{6}{|l|}{ \# 76 m } \\
\hline Days 23-60 & $120 \mathrm{~W} \mathrm{~m}^{2}$ & 0.79 & $\left(4.04 W m{ }^{1} K^{1}\right)$ & $\left(0.08 W m^{2} K^{1}\right)$ & $4.6^{\circ} \mathrm{C}$ \\
\hline Days $80-115$ & $44 \mathrm{~W} \mathrm{~m}^{2}$ & 0.37 & $\left(0.70 W \mathrm{~W}^{1} \mathrm{~K}^{1}\right)$ & $\left(0.08 W m^{2} K^{1}\right)$ & $10.2^{\circ} \mathrm{C}$ \\
\hline \multicolumn{6}{|l|}{$\# 82 \mathrm{~m}$} \\
\hline Days 23-60 & $124 \mathrm{~W} \mathrm{~m}^{2}$ & 0.68 & $0.82 \mathrm{~W} \mathrm{~m}^{1} \mathrm{~K}^{1}$ & $2.00 \mathrm{~W} \mathrm{~m}^{2} \mathrm{~K}^{1}$ & $4.6{ }^{\circ} \mathrm{C}$ \\
\hline Days $80-115$ & $64 \mathrm{~W} \mathrm{~m}^{2}$ & 0.43 & $0.36 \mathrm{~W} \mathrm{~m}^{1} \mathrm{~K}^{1}$ & $0.40 \mathrm{~W} \mathrm{~m}^{2} \mathrm{~K}^{1}$ & $5.4^{\circ} \mathrm{C}$ \\
\hline \multicolumn{6}{|l|}{ \# 89 m } \\
\hline Days 23-60 & $256 \mathrm{~W} \mathrm{~m}^{2}$ & 0.62 & $1.03 \mathrm{~W} \mathrm{~m}{ }^{1} \mathrm{~K}^{1}$ & $8.96 \mathrm{~W} \mathrm{~m}^{2} \mathrm{~K}^{1}$ & $3.1{ }^{\circ} \mathrm{C}$ \\
\hline Days $80-115$ & $268 \mathrm{~W} \mathrm{~m}^{2}$ & 0.44 & $\left(1.88 W \mathrm{~m}^{1} \mathrm{~K}^{1}\right)$ & $\left(4.08 \mathrm{Wm}^{2} \mathrm{~K}^{1}\right)$ & $12.5^{\circ} \mathrm{C}$ \\
\hline \multicolumn{6}{|l|}{ Condenser $91.5 \mathrm{~m}$} \\
\hline Days 23-60 & $128 \mathrm{~W} \mathrm{~m}^{2}$ & 0.68 & $\left(1.97 W \mathrm{~W}^{1} \mathrm{~K}^{1}\right)$ & $\left(6.96 W m^{2} K^{1}\right)$ & $1.8 \mathrm{~mm} /$ day \\
\hline Days $80-115$ & $32 \mathrm{~W} \mathrm{~m}^{2}$ & 0.69 & $\left(0.45 W m^{1} K^{1}\right)$ & $\left(3.60 W m^{2} K^{1}\right)$ & $0.3 \mathrm{~mm} /$ day \\
\hline \multicolumn{6}{|l|}{ \# $94 \mathrm{~m}$} \\
\hline Days 23-60 & $128 \mathrm{~W} \mathrm{~m}^{2}$ & 1.00 & $1.29 \mathrm{~W} \mathrm{~m}^{1} \mathrm{~K}^{1}$ & $1.84 \mathrm{~W} \mathrm{~m}^{2} \mathrm{~K}^{1}$ & $3.7^{\circ} \mathrm{C}$ \\
\hline Days $80-115$ & $138 \mathrm{~W} \mathrm{~m}^{2}$ & 0.88 & $0.94 \mathrm{~W} \mathrm{~m}^{1} \mathrm{~K}^{1}$ & $0.84 \mathrm{~W} \mathrm{~m}^{2} \mathrm{~K}^{1}$ & $10.5^{\circ} \mathrm{C}$ \\
\hline \multicolumn{6}{|l|}{ \# 101 m } \\
\hline Days 23-60 & $128 \mathrm{~W} \mathrm{~m}^{2}$ & 0.97 & $1.38 \mathrm{~W} \mathrm{~m}^{1} \mathrm{~K}^{1}$ & $3.92 \mathrm{~W} \mathrm{~m}^{2} \mathrm{~K}^{1}$ & $3.1^{\circ} \mathrm{C}$ \\
\hline Days $80-115$ & $136 \mathrm{~W} \mathrm{~m}^{2}$ & 0.63 & $0.99 \mathrm{~W} \mathrm{~m}{ }^{1} \mathrm{~K}^{1}$ & $3.04 \mathrm{~W} \mathrm{~m}^{2} \mathrm{~K}^{1}$ & $5.9^{\circ} \mathrm{C}$ \\
\hline
\end{tabular}




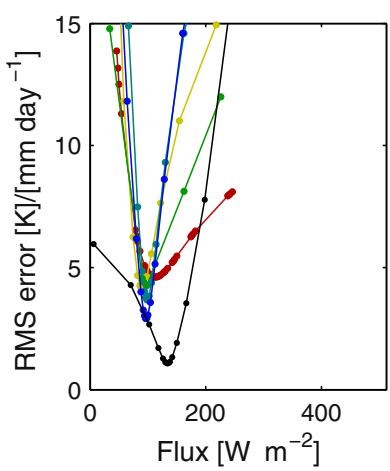

Flux $\left[\mathrm{W} \mathrm{m} \mathrm{m}^{-2}\right]$

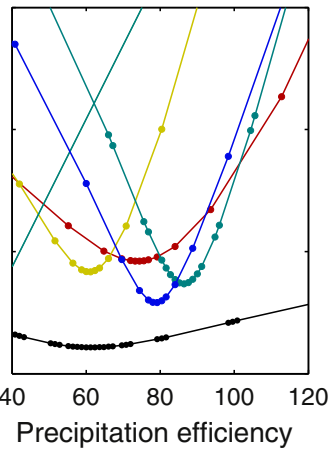

[\%]

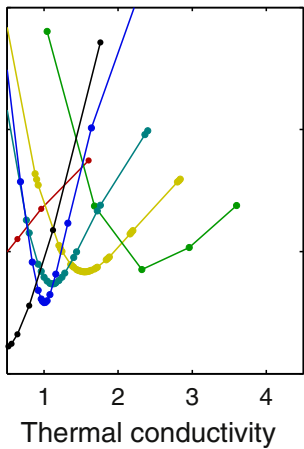

$\left[\mathrm{W} \mathrm{K}^{-1} \mathrm{~m}^{-1}\right]$

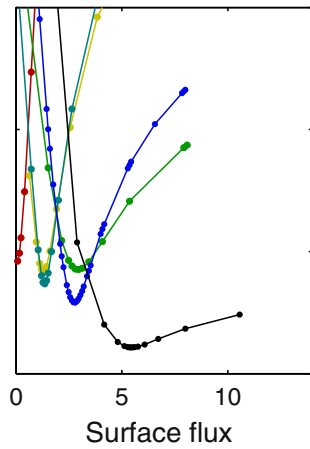

coefficient $\left[\mathrm{W} \quad \mathrm{m}^{-2} \mathrm{~K}^{-1}\right]$

$\longrightarrow$ —

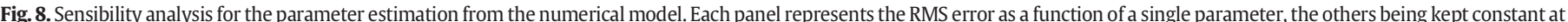

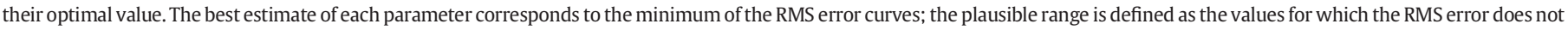
exceed by more than $20 \%$ the RMS error of the best set of parameters. Thus, narrower apertures of the curve indicate best constrained estimations.

the radiative flux, and at least $10 \mathrm{~W} \mathrm{~m}^{-2} \mathrm{~K}^{-1}$ for the sensible flux (depending on the wind conditions). This can be linked to the unexpect edly large thermal gradient measured on day 55 between $10 \mathrm{~cm}$ depth (55 $95{ }^{\circ} \mathrm{C}$ depending on the profile) and the surface observed during the helicopter survey (between 22 and $38^{\circ} \mathrm{C}$, see Fig. 2c). This might be due to heterogeneous physical parameters, and in particular decrease of the thermal conductivity on the shallowest layers. Indeed, variations of the soil moisture up to $30 \%$ in the shallowest layers of the fumarolic zones have been previously reported at Karapiti (Hochstein and Bromley, 2005) and by numerical modeling (Chiodini et al., 2005), the highest values corresponding to the condensation zone, between 7 and $15 \mathrm{~cm}$ below the surface. However, a saturation drop by $1030 \%$ as observed at Karapiti (Hochstein and Bromley, 2005) can only account for a $30 \%$ decrease of the thermal conductivity (Chiodini et al., 2005). Another hypothesis is based on the fact that Gaudin et al. (2013)) did not observe this anomalous gradient in punctual

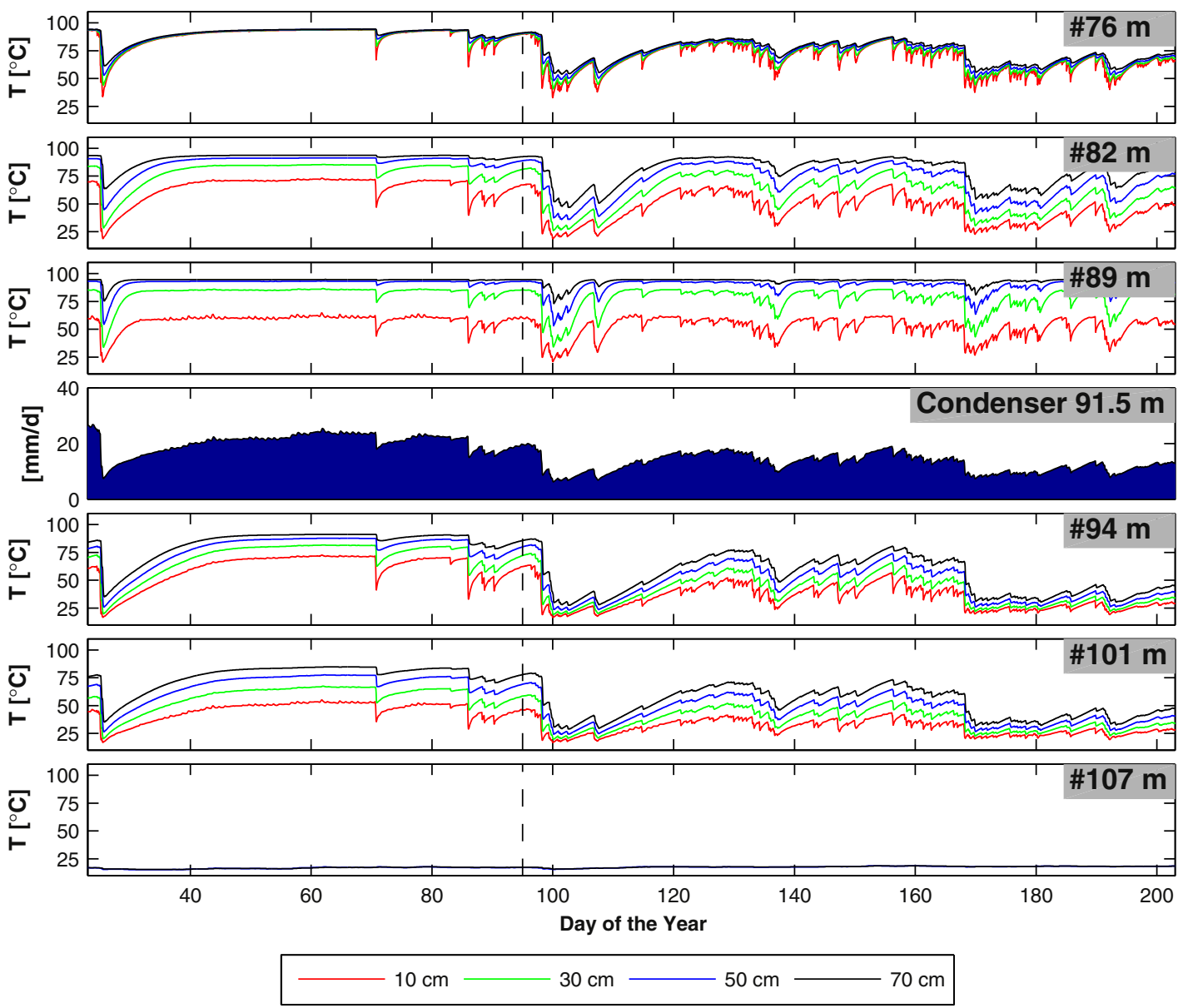

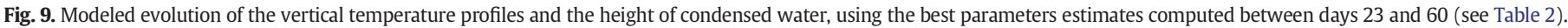


measurements achieved in 2012. Thus, we may consider that the thick ness of the ground above the first thermometers might have increase after the set up of the station, for example due to small landslides.

\subsection{Modeling of the long term evolution of the TFFZ}

Using the parameters of days 2560 , our numerical model allows reconstructing the global evolution of the temperature during the 6 months of the experiment (Fig. 9). Results are very similar to observa tions (Fig. 5). In particular, the different behaviors during the wet period (no cooling, partial cooling and total cooling) are well predicted by the model. These observations validate a posteriori the assumptions of our model, and suggest that the fluxes and physical parameters of the ground did not vary significantly during the 6 months of the observa tions. Conversely, the large discrepancies between the predicted and the observed condenser data highlights again that the variations of steam flow in the condenser cannot be explained assuming constant geothermal flux and/or physical parameters of the ground.

\section{Discussion}

\subsection{Validity of simplifying assumptions}

Our model is designed to provide simple relationships between the different parameters of the ground and allow direct use during field campaigns to describe the short term behavior of diffuse degassing zones. For this reason, it relies on the fact that heat and water circulation can be described by one dimensional equations and constant parame ters. The reliability of our modeling is demonstrated both by the very good agreement between the simulated and the observed data (Figs. 5 and 9) and by the concordance between the physical parameters estimated by the model and previous studies (Section 5.3).

The assumption that physical parameters are homogeneous is based on the fact that we limit the study to the shallowest $2 \mathrm{~m}$, corresponding to the top of the convective layer that is at least 30 m thick at TFFZ (Brothelande et al., 2014). Such assumption is supported by the homo geneity of the soil observed during the digging of the trench. However, temporal variability and spatial variability of the water content (Chiodini et al., 2005; Hochstein and Bromley, 2005) have a significant effect on the permeability of the soil (Fredlund et al., 1994), its density, its heat capacity, and its thermal conductivity (Woodside and Messmer, 1961). These phenomena, which were neglected in this study, might be the cause of the strikingly high temperature gradients observed on the shallowest $10 \mathrm{~cm}$ (see Section 5.3).

Similarly, heat and water fluxes are assumed to have no lateral component. In particular, the possible ground water flow from the dome that might cool the zone is not taken into account. Indeed, there is no significant permeability or pressure contrast in our study domain, so there is no reason that lateral fluxes or flows occur. Note that this assumption would not be valid at larger scales where significant permeability contrasts (e.g. Coutant et al., 2012; Lesparre et al., 2012; Brothelande et al., 2014) would cause the channeling of fluxes by the geological structures. For these cases, more complex models based on fluid dynamics equations have to be used (e.g. Chiodini et al., 2005; Petrillo et al., 2013). However, for the surveys concerning surface flux estimation for which a limited number of devices are used, such complexity would require more parameter estimations and induce uncertainties.

Finally, the surface flux may be more precisely described, using the formulation of Gaudin et al. (2013) or a simplified model where the surface flux coefficient would be proportional to the wind velocity. However, this would require additional measurements, including wind velocity and sun illumination, and considering their uncertainties, would not necessarily improve the final precision of the model.

\subsection{Reliability of geothermal flux retrieval methods}

This study highlights the reliability and the limitations of two methods used to measure the geothermal flux of fumarolic zones at steady state: the measurement vertical temperature gradient and the direct monitoring of the steam flow via a condenser. As for other techniques (e.g. surface temperature measurement, e.g. Sekioka and Yuhara (1974); Gaudin et al. (2013))), the precision relies mainly on 1) the uncertainties of the measurements, 2) the validity of the equilib rium assumption, and 3 ) the estimation of the parameters.

\subsubsection{Uncertainties rising from the setup}

As mentioned above, uncertainties can rise from the setup itself. For instance, using the temperature gradient requires that thermometers are located in the conductive layer. In Table 2, reliable estimations are achieved only for the vertical profiles \#89 m, \#94 m and \#101 m, where at least two thermometers are located within the conductive layer. The setup itself can also disturb the fluxes. In particular, the condenser must be set up deep enough so that the conductive flux can be considered as negligible which dramatically enhance the chimney effect (Fig. A2). The correction proposed in Appendix A allows retrieving reliable fluxes, but without the error estimation. In addition, we inter pret the decrease of the steam flow below the condenser (Table 2) as a drop of the permeability, possibly due to the chimney effect of the condenser increasing the steam flow (Appendix A) and favoring the mineral deposition. Unfortunately, the setup was damaged by a land slide after 6 months, and this hypothesis could not be tested further.

\subsubsection{Equilibrium assumption}

In order to retrieve the total geothermal flux, the total heat flux must be constant in the whole column (Eq. (6)), which is the case only at steady state. Since the geothermal flux and the physical parameters are expected to vary on large timescales (months to years), disturbances of the equilibrium are only due to meteorological influences. Thermal waves are due to the diurnal variation of the insolation and atmosphere temperature. They are visible in most thermal sensors and in the condenser (Fig. 5), with amplitude divided by approx. 5 each $20 \mathrm{~cm}$ (Turcotte and Schubert, 2002). In this study, we remove these waves by averaging the data on $24 \mathrm{~h}$. Another solution would consist in mea suring the heat flux generated by the thermal wave in a zone without geothermal flux and subtract it from the estimations (Gaudin et al., 2013).

Rainfall events have a larger and longer impact on the fluxes. Their effect can be described by considering the heat necessary to warm the effective rainfall to boiling temperature. Thus, a characteristic time can be computed assuming that all the geothermal flux is used for re heating the ground, that is to say, the surface fluxes vanish:

$t \quad \frac{H \rho_{w} c_{w}\left(T_{b o}-T_{a t m}\right)}{Q}$

where $H$ is the efficient rainfall height. For the rainfall episode of day 25 , the theoretical values of $t$ range between 2 days (vertical profile \#82 m) and 6.3 days (vertical profile \#101 m). These theoretical values are slightly smaller than the observations (Fig. 7), because a fraction of the geothermal flux is released to the atmosphere. However, this criterion can be used to estimate at first order if the system is close to equilibrium.

\subsubsection{Estimation of the physical parameters}

Flux estimation methods also require the estimation of physical parameters, including the conductivity, density, and sensible heat of the ground. These parameters can be estimated through our numerical model. The reliability of the results can be estimated by two ways. First, Fig. 8 allows for determining to which extent they are constrained by 
our model inversion. Additionally, uncertainties can be determined by comparing the results in two different time periods (Table 2).

The first study period (days 23 60) is associated with the lowest RMS errors. Thermal conductivity ranges between 0.82 and $1.38 \mathrm{~W} \mathrm{~m}^{-1} \mathrm{~K}^{-1}$ with uncertainties of about $20 \%$. Such values are com patible with previous studies (Robertson, 1988; Brigaud and Vasseur, 1989) for non porous rocks. Indeed, the saturation of the pores by water may dramatically decrease the thermal insulation provided by the porosity. Precipitation efficiency coefficient ranges between 0.5 and 1, 0.6 corresponding to the coefficient at the rain gauge. Here again, the uncertainties are about $20 \%$, and the observed horizontal var iations remain under the uncertainty level.

\subsubsection{Uncertainties on the flux estimation}

Finally, the dispersion (standard deviation) on the heat flux estima tions by different methods is lower than $10 \%$ in the best cases (Table 1 ), but rises dramatically if the thermometers are not located in the conductive layer. Concerning the condenser, the comparison between the flux estimated at equilibrium (Section 5.1) and the flux retrieved by the model (Section 5.3) suggests uncertainties of $20 \%$, but this result could not be reproduced during the second time period. In the case of instantaneous measurements, the uncertainties on the distance between two successive thermometers $( \pm 10 \%)$ and the parameters retrieval ( $\pm 20 \%)$ must be taken into account. As a consequence, the total uncertainties on the retrieved flux are around $25 \%$.

\subsection{Thermal evolution of low flux fumarolic zones}

From a more general point of view, this study gives some essential insights on the evolution of low flux fumarolic zones. At first order, we demonstrated that the evolution of the zone is strongly influenced by the ratio between the precipitations and the geothermal flux. By replacing the rainfall height $H$ by the average effective rainfall rate $\overline{\varphi_{r}}$ in Eq. (11), an adimensional index $\alpha$ can be defined to predict the thermal behavior of any hydrothermal zone:

$\frac{1}{\alpha} \frac{\overline{\varphi_{r}} \rho_{w} c_{w}\left(T_{b o}-T_{a t m}\right)}{Q}$

If $\alpha$ is lower than 1 , the geothermal flux is not sufficient to heat all the effective precipitations, and the sensible energy of the soil keeps on de creasing, inducing a progressive sink of the condensation layer and the inactivation of the zone. For example, between days 170 and 195, the mean effective rainfall rate is $37 \mathrm{~mm}^{-1 a y}{ }^{-1}$, corresponding to a mini mum flux of $142 \mathrm{~W} \mathrm{~m}^{-2}$. The $\alpha$ indexes of all profiles except $\# 82 \mathrm{~m}$ drop below 1 , in good accordance with the observed decreasing temper atures (Fig. 5). At the scale of the year, $\overline{\varphi_{r}}$ is about $18 \mathrm{~mm}$ day $^{-1}$, which corresponds to a limit of about $60 \mathrm{~W} \mathrm{~m}^{-2}$. Below this threshold, the ac tivity of the zone must stop permanently.

Apart from meteorological conditions, variations of the geothermal flux at the surface can be due either to changes in the hydrothermal circulation in depth (e.g. opening or closing of fractures, rise of magma intrusions) or changes in the permeability of the sub surface (Ricci et al., submitted for publication). It has been widely observed that the hydrothermal activity enhances depositions, which progressively de crease the permeability. At the TFFZ, an intense argilization occurs, and may lead to the sealing of the area in a few years (Salaün et al., 2011). Although our survey was not long enough to distinguish and quantify these effects, we suggest that the pausing of the hydrothermal activity due to a drop of the $\alpha$ index might stop the hydrothermal sealing preserving a relatively high permeability. Thus, when the activ ity increases again, former hydrothermal zones are more easily reactivated. Such reactivations have been observed during the two last crises at La Soufrière (Jolivet, 1958; Zlotnicki et al., 1992).

Finally, observed heterogeneities of geothermal flux and physical parameters suggest that complex fluid path may occur at the scale of the entire anomaly. Global circulation of steam and water are out of the scope of our 1D model. In particular, the ground water flowing from the dome was not considered. Indeed, condensed water is expect ed to circulate at the base of the permeable layer, that is to say a few tens of meters below the ground. However, further analysis with higher vertical and horizontal resolutions are scheduled to draw a map of the anomaly and to infer the lateral fluid and heat fluxes at this scale. At the scale of the edifice, fluid circulation is even more complex because the large permeability contrasts suggested by muon density (Lesparre et al., 2012), gravimetry and seismic tomographies (Coutant et al., 2012) will produce complex condensed water, steam and gas circula tions, that are not in the scope of this paper.

\section{Conclusion}

In this study, we compared two complementary methods of flux estimation. On one hand, measurement of vertical temperature profiles is relatively easy to set up, and minimally invasive, making it suitable for surveys on wider areas. On the other hand, direct measurement of the steam flow through a condenser requires heavy infrastructures, but it could be used for more extended survey, including for example contin uous chemical gas analysis. Both methods are subject to similar issues, which can be classified into: 1 ) technical problems, mainly due to the very wet and acidic environment that damaged 5 out of 22 thermome ters, 2) uncertainties on the physical parameters that are required to convert the observations into a flux (e.g. thermal conductivity or radius of the influence area of the condenser), and 3) assumption of the steady state.

This work demonstrates that a simple one dimensional model provides realistic relationships to assess the validity of this latter assumption. Meanwhile, a numerical model can be used to improve the precision and the reliability of the results by providing an estimation of the physical parameters. In all cases, we estimate the 1 standard deviation random error to be around $10 \%$, and systematic errors around $25 \%$, due to the estimation of the physical parameters and the setup.

More generally, this study allows quantifying the evolution of a fumarolic zone subject to variable rainfalls. We demonstrated that precipitations have a prevailing influence on the surface manifestations of the hydrothermal flux. By introducing the $\alpha$ index (Eq. 11), we propose that zones with a geothermal flux lower than a given threshold ( $60 \mathrm{~W} / \mathrm{m}^{2}$ at La Soufrière) become inactive and do not present any flux in surface. Due to the absence of fluid circulation, alteration might remain at a low level, and a relatively high permeability might be pre served. Consequently, in case of increase of the hydrothermal activity, these zones could thus be easily reactivated (Jolivet, 1958; Zlotnicki et al., 1992).

\section{Acknowledgments}

The authors warmly thank the Campbell Scientific France team for their advice and support, the local assistance of the OVSG team and an anonymous reviewer for its careful review of the manuscript. The research leading to these results has received funding from the ANR Domoscan, Programme Transverse en Recherches Volcanologiques (PTRV), and from the People Programme (Marie Curie Actions) of the European Union's Seventh Framework Programme (FP7/2007 2013) under the project $N E M O H$, REA grant agreement $n^{\circ} 289976$. This is IPGP contribution number: 3643.

\section{Appendix A. Quantification of the chimney effect of the condenser}

The condenser is constituted of a $45 \mathrm{~cm}$ diameter metal cylinder, buried at $30 \mathrm{~cm}$ depth and opened to the atmosphere by a $35 \mathrm{~mm}$ valve (Fig. 4). It acts as a chimney, by forcing the pressure at its base to be equal to the atmospheric pressure, which perturbs the steam fluxes below it. 


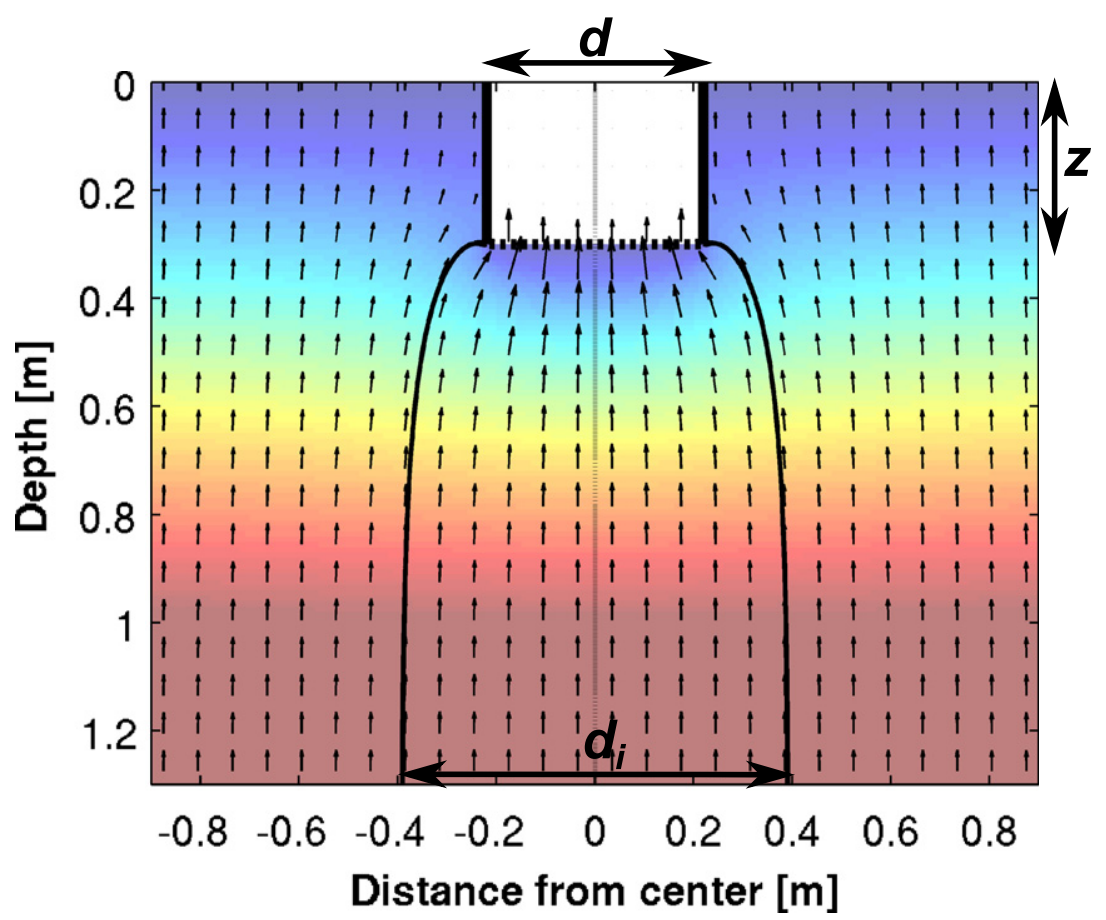

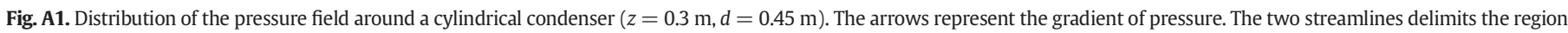
flowing into the condenser. In depth, the diameter $d_{i}$ of this region is equal to $0.81 \mathrm{~m}$.

In order to quantify these perturbations, we computed the pressure field next to the condenser. Assuming that the pressure is homogeneous at depth and at the surface, we modeled a cylindrical box, with a diam eter $d$ and buried at a depth $z$, opened at the base and the top. Neglecting the changes in the fluid densities, the mass conservation imposes that the divergence of the gas velocity field is null. According to the Darcy law, and assuming that the permeability is constant, we deduce that the Laplacian of the pressure must be null as well:

$\Delta P \quad 0$

The numerical resolution of this equation in a cylindrical referential allows computing the pressure field, and the direction of the gas flow,

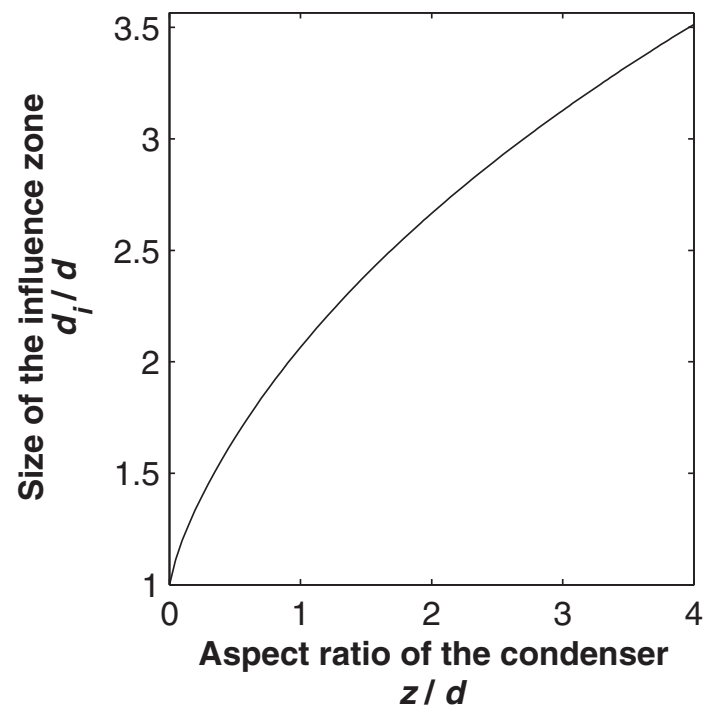

Fig. A2. Estimation of the diameter of the condenser influence zone, as a function of its aspect ratio. parallel to the pressure gradient (Fig. A1). Thus, we can derive the influence diameter of the condenser $\left(d_{i}\right)$, representing the area drained by the condenser (Fig. A1).

Normalization of the equations demonstrates that the $d_{i} / d$ depends only on the $z / d$ ratio. Indeed, the perturbation increases when the $z / d$ ratio increases (Fig. A2). From the dimensions of the condenser, we deduce that the influence diameter is 1.8 larger than the condenser one. In other words, the drained surface is 3.2 times larger than the base of the condenser.

\section{References}

Abu-Hamdeh, N.H., 2003. Thermal properties of soils as affected by density and water content. Biosyst. Eng. 86 (1), 97-102. http://dx.doi.org/10.1016/S1537-5110(03)00112-0. Allard, P., Hammouya, G., Parello, F., 1998. Dégazage magmatique diffus à la Soufrière de Guadeloupe, Antilles. Comptes Rendus Académie Sci. - Ser. IIA - Earth Planet. Sci. 327 (5), 315-318. http://dx.doi.org/10.1016/S1251-8050(98)80049-9.

Allard, P., Aiuppa, A., Beauducel, F., Gaudin, D., Di Napoli, R., Calabrese, S., Parello, F., Crispi, O., Hammouya, G., Tamburello, G., 2014. Steam and gas emission rate from La Soufriere volcano, Guadeloupe (Lesser Antilles): implications for the magmatic supply during degassing unrest. Chem. Geol. 384, 76-93. http://dx.doi.org/10.1016/ j.chemgeo.2014.06.019.

Allemand, P., Delacourt, C., Lajeunesse, E., Devauchelle, O., Beauducel, F., 2014. Erosive effects of the storm Helena (1963) on Basse Terre Island (Guadeloupe - Lesser Antilles Arc). Geomorphology 206, 79-86. http://dx.doi.org/10.1016/j.geomorph.2013.09.020.

Aubert M. 1999. Practical evaluation of steady heat discharge from dormant active volcanoes: case study of Vulcarolo fissure (Mount Etna, Italy). J. Volcanol. Geotherm. Res. 92 (3-4), 413-429. http://dx.doi.org/10.1016/S0377-0273(99)00088-8.

Aubert, M., Diliberto, S., Finizola, A., Chébli, Y., 2008. Double origin of hydrothermal convective flux variations in the Fossa of Vulcano (Italy). Bull. Volcanol. 70 (6), 743-751. http://dx.doi.org/10.1007/s00445-007-0165-y.

Beauducel, F., 2001. High-resolution digital elevation model of La Soufrière lava dome OVSG database, Institut de Physique du Globe de Paris, Gourbeyre, Guadeloupe, FWI.

Bennati, L., Finizola, A., Walker, J., Lopez, D., Higuiera-Diaz, C., Schütze, C., Barahona, F., Cartagena, R., Conde, V., Funes, R., Rios, C., 2011. Fluid circulation in a complex volcano-tectonic setting, inferred from self-potential and soil $\mathrm{CO}_{2}$ flux surveys: the Santa María-Cerro Quemado-Zunil volcanoes and Xela caldera (northwestern Guatemala). J. Volcanol. Geotherm. Res. 199, 216-229. http://dx.doi.org/10.1016/j. jvolgeores.2010.11.008.

Boudon, G., Komorowski, J.-C., Villemant, B., Semet, M.P., 2008. A new scenario for the last magmatic eruption of La Soufrière of Guadeloupe (Lesser Antilles) in 1530 A.D. Evidence from stratigraphy radiocarbon dating and magmatic evolution of erupted products. J. Volcanol. Geotherm. Res. 178 (3), 474-490. http://dx.doi.org/10.1016/j. jvolgeores.2008.03.006. 
Brigaud, F., Vasseur, G., 1989. Mineralogy, porosity and fluid control on therma conductivity of sedimentary rocks. Geophys. J. Int. 98 (3), 525-542. http://dx.doi org/10.1111/j.1365-246X.1989.tb02287.x.

Brombach, T., Marini, L., Hunziker, J.C., 2000. Geochemistry of the thermal springs and fumaroles of Basse-Terre Island, Guadeloupe, Lesser Antilles. Bull. Volcanol. 61 (7) 477-490. http://dx.doi.org/10.1007/PL00008913.

Brothelande, E., Finizola, A., Peltier, A., Delcher, E., Komorowski, J.-C., Di Gangi, F., Borgogno, G., Passarella, M., Trovato, C., Legendre, Y., 2014. Fluid circulation pattern inside La Soufrière volcano (Guadeloupe) inferred from combined electrical resistivity tomography, self-potential, soil temperature and diffuse degassing measurements. J. Volcanol. Geotherm. Res. 288, 105-122. http://dx.doi.org/10.1016/j.jvolgeores. 2014.10.007.

Carson, J.K., Lovatt, S.J., Tanner, D.J., Cleland, A.C., 2005. Thermal conductivity bounds for isotropic, porous materials. Int. J. Heat Mass Transf. 48 (11), 2150-2158. http://dx.doi.org/10.1016/j.ijheatmasstransfer.2004.12.032.

Chaperon, P., L'Hote, Y., Vuillaume, G., 1983. Les ressources en eau de surface de la Guadeloupe. Cah. ORSTOM 20 (3-4), 149-178.

Chiodini, G., Frondini, F., Cardellini, C., Granieri, D., Marini, L., Ventura, G., 2001. CO degassing and energy release at Solfatara volcano, Campi Flegrei, Italy. J. Geophys. Res. 106 (B8), 16213-16221. http://dx.doi.org/10.1029/2001JB000246.

Chiodini, G., Granieri, D., Avino, R., Caliro, S., Costa, A., Werner, C., 2005. Carbon dioxyde diffuse degassing and estimation of hest release from volcanic and hydrotherma systems. J. Geophys. Res. 110. http://dx.doi.org/10.1029/2004JB003542 B08204.

Corwin, R.F., Hoover, D.B., 1979. The self-potential method in geothermal exploration. Geophysics 44 (2), 226-245. http://dx.doi.org/10.1190/1.1440964.

Coutant, O., Bernard, M.L., Beauducel, F., Nicollin, F., Bouin, M.P., Roussel, S., 2012. Joint inversion of P-wave velocity and density, application to La Soufrière of Guadeloupe hydrothermal system. Geophys. J. Int. 191 (2), 723-742. http://dx.doi.org/10.1111/j. 1365-246X.2012.05644.X.

Feuillard, M., Allegre, C.J., Brandeis, G., Gaulon, R., Le Mouel, J.L., Mercier, J.C., Pozzi, J.P., Semet, M.P., 1983. The 1975-1977 crisis of la Soufriere de Guadeloupe (F.W.I): a still-born magmatic eruption. J. Volcanol. Geotherm. Res. 16 (3-4), 317-334. http://dx.doi.org/10.1016/0377-0273(83)90036-7.

Feuillet, N., Manighetti, I., Tapponnier, P., Jacques, E., 2002. Arc parallel extension and localization of volcanic complexes in Guadeloupe, Lesser Antilles. J. Geophys. Res. Solid Earth 107 (B12), 2331. http://dx.doi.org/10.1029/2001JB000308.

Finizola, A., Sortino, F., Lénat, J.-F., Valenza, M., 2002. Fluid circulation at Stromboli Volcano (Aeolian Islands, Italy) from self-potential and $\mathrm{CO}_{2}$ surveys. J. Volcanol. Geotherm. Res. 116 (1), 1-18. http://dx.doi.org/10.1016/S0377-0273(01)00327-4.

Finizola, A., Ricci, T., Deiana, R., Barde-Cabusson, S., Rossi, M., Praticelli, N., Giocoli, A. Romano, G., Delcher, E., Suski, B., Revil, A., Menny, P., Di Gangi, F., Letort, J., Peltier, A., Villasante-Marcos, V., Douillet, G., Avard, G., Lelli, M., 2010. Adventive hydrothermal circulation on Stromboli volcano (Aeolian Islands, Italy) revealed by geophysica and geochemical approaches: implications for general fluid flow models on volcanoes. J. Volcanol. Geotherm. Res. 196 (1), 111-119. http://dx.doi.org/10.1016/j. jvolgeores.2010.07.022.

Fredlund, D.G., Xing, A., Huang, S., 1994. Predicting the permeability function for unsaturated soils using the soil-water characteristic curve. Can. Geotech. J. 31 (4), 533-546. http://dx.doi.org/10.1139/t94-062.

Gaudin, D., Beauducel, F., Allemand, P., Delacourt, C., Finizola, A. 2013. Heat flux measurement from thermal infrared imagery in low-flux fumarolic zones: example of the Ty fault (La Soufrière de Guadeloupe). J. Volcanol. Geotherm. Res. 267, 47-56. http://dx.doi.org/10.1016/j.jvolgeores.2013.09.009.

Gerlach, T.M., 1980. Evaluation of volcanic gas analysis from Surtsey volcano, Iceland 1964-1967. J. Volcanol. Geotherm. Res. 8 (2-4), 191-198. http://dx.doi.org/10. 1016/0377-0273(80)90104-3.

Harris, A., 2013. Thermal Remote Sensing of Active Volcanoes: A User's Manual. Cambridge University Press.

Harris, A., Maciejewski, A., 2000. Thermal surveys of the Vulcano Fossa fumarole field 1994-1999: evidence for fumarole migration and sealing. J. Volcanol. Geotherm. Res. 102 (1-2), 119-147. http://dx.doi.org/10.1016/S0377-0273(00)00184-0.

Hillel, D., 1982. Introduction to Soil Physics. Academic press, New York.

Hochstein, M.P., Bromley, C.J., 2005. Measurement of heat flux from steaming ground. Geothermics 34 (2), 131-158. http://dx.doi.org/10.1016/j.geothermics.2004.04.002.

Jolivet, J., 1958. La crise volcanique de 1956 à la Soufrière de la Guadeloupe. Ann. Geophys. 14, 305. http://dx.doi.org/10.1186/2191-5040-3-3.

Komorowski, J.-C., Boudon, G., Semet, M.P., Beauducel, F., Anténor-Habazac, V., Bazin, S. Hammouya, G., Cheminée, J.-L., 2005. Volcanic Atlas of the Lesser Antilles. University of the West Indies, pp. 63-100.

Lesparre, N., Gibert, D., Marteau, J., Komorowski, J.-C., Nicollin, F., Coutant, O., 2012 Density muon radiography of La Soufrière of Guadeloupe volcano: comparison with geological, electrical resistivity and gravity data. Geophys. J. Int. 190 (2), 1008-1019.

Lowell, R.P., 1991. Modeling continental and submarine hydrothermal systems. Rev. Geophys. 29 (3), 457-476. http://dx.doi.org/10.1029/91RG01080.
Luna, E., Córdova, A., Medina, A., Higuera, F.J., 2002. Convection in a finite tilted fracture in a rock. Phys. Lett. A 300 (4-5), 449-455. http://dx.doi.org/10.1016/S03759601(02)00755-7.

Nicollin, F., Gibert, D., Beauducel, F., Boudon, G., Komorowski, J.-C., 2006. Electrical tomography of La Soufrière of Guadeloupe Volcano: field experiments, 1D inversion and qualitative interpretation. Earth Planet. Sci. Lett. 244 (3-4), 709-724. http://dx.doi.org/10.1016/j.epsl.2006.02.020.

Opfergelt, S, Georg, R.B., Delvaux, B., Cabidoche, Y.-M, Burton, KW Halliday, A.N., 2012 Silicon isotopes and the tracing of desilication in volcanic soil weathering sequences Guadeloupe. Chem. Geol. 326-327, 113-122. http://dx.doi.org/10.1016/j.chemgeo. 2012.07.032.

OVSG-IPGP, 2010. Météo Multi-Paramètres: "Soufrière - Piton Sanner." Observatoire Volcanologique et Sismologique de la Guadeloupe. Institut de Physique du Globe de Paris.

OVSG-IPGP, 2014. Bilan Mensuel de l'Activité Volcanique de la Soufrière et de la Sismicité régionale.

Peltier, A., Finizola, A., Douillet, G.A., Brothelande, E., Garaebiti, E., 2012. Structure of an active volcano associated with a resurgent block inferred from thermal mapping: The Yasur-Yenkahe volcanic complex (Vanuatu). J. Volcanol. Geotherm. Res. 243-244, 59-68. http://dx.doi.org/10.1016/j.jvolgeores.2012.06.022.

Petrillo, Z., Chiodini, G., Mangiacapra, A., Caliro, S., Capuano, P., Russo, G., Cardellini, C., Avino, R., 2013. Defining a 3D physical model for the hydrothermal circulation at Campi Flegrei caldera (Italy). J. Volcanol. Geotherm. Res. 264, 172-182. http://dx. doi.org/10.1016/j.jvolgeores.2013.08.008.

Pielke, R.A., 2013. Mesoscale Meteorological Modeling. 3rd ed. Elsevier Academic Press, Oxford (UK)

Pribnow, D.F.C., Schütze, C., Hurter, S.J., Flechsig, C., Sass, J.H., 2003. Fluid flow in the resurgent dome of Long Valley Caldera: implications from thermal data and deep electrical sounding. J. Volcanol. Geotherm. Res. 127, 329-345. http://dx.doi.org/10.1016/ S0377-0273(03)00175-6.

Pruppacher, H.R., Klett, J.D., 2000. Microphysics of Clouds and Precipitation. Kluwer Academic Publishers, Dordrecht (The Netherlands).

Revil, A., Finizola, A., Piscitelli, S., Rizzo, E., Ricci, T., Crespy, A., Angeletti, B., Balasco, M., Barde Cabusson, S., Bennati, L., Bolève, A., Byrdina, S., Carzaniga, N., Di Gangi, F., Morin, J., Perrone, A., Rossi, M., Roulleau, E., Suski, B., 2008. Inner structure of La Fossa di Vulcano (Vulcano Island, southern Tyrrhenian Sea, Italy) revealed by highresolution electric resistivity tomography coupled with self-potential, temperature, and CO2 diffuse degassing measurements. J. Geophys. Res. Solid Earth 113 (B7). http://dx.doi.org/10.1029/2007JB005394.

Ricci, T., Finizola, A., Barde-Cabusson, S., Delcher, E., Alparone, S., Gambino, S., Milluzzo, V., 2015. Hydrothermal system pressurization evidenced by sub-surface changes in heat transfer modality: the La Fossa cone of Vulcano case study. Geology (submitted for publication).

Robertson, E.C., 1988. Thermal Properties of Rocks. US Department of the Interior, Geological Survey.

Salaün, A., Villemant, B., Gérard, M., Komorowski, J.-C., Michel, A., 2011. Hydrothermal alteration in andesitic volcanoes: trace element redistribution in active and ancient hydrothermal systems of Guadeloupe (Lesser Antilles). J. Geochem. Explor. 111 (3), 59-83. http://dx.doi.org/10.1016/j.gexplo.2011.06.004.

Sekioka, M., Yuhara, K., 1974. Heat flux estimation in geothermal areas based on the heat balance of the ground surface. J. Geophys. Res. 79 (14), 2053-2058.

Sheridan, M.F., 1970. Fumarolic mounds and ridges of the Bishop Tuff California. Geol. Soc. Am. Bull. 81 (3), 851-868. http://dx.doi.org/10.1130/0016-7606(1970)81[851: FMAROT]2.0.CO;2.

Turcotte, D.L., Schubert, G., 2002. Geodynamics. Cambridge University Press.

Villemant, B., Komorowski, J.C., Dessert, C., Michel, A., Crispi, O., Hammouya, G., Beauducel, F., De Chabalier, J.B., 2014. Evidence for a new shallow magma intrusion at La Soufrière of Guadeloupe (Lesser Antilles): insights from long-term geochemical monitoring of halogen-rich hydrothermal fluids. J. Volcanol. Geotherm. Res. 285, 247-277. http://dx.doi.org/10.1016/j.jvolgeores.2014.08.002.

Woodside, W., Messmer, J.H., 1961. Thermal conductivity of porous media I. Unconsolidated sands. J. Appl. Phys. 32 (9), 1688-1699. http://dx.doi.org/10.1063/1.1728419.

Yuhara, K., Sekioka, M., Ehara, S., 1978. Infrared measurement on Satsuma-iwojima island, Kagoshima, Japan, by helicopter-borne thermocamera. Arch. Meteorol. Geophys. Bioklimatol. A 27 (2), 171-181.

Yuhara, K., Ehara, S., Tagomori, K., 1981. Estimation of heat discharge rates using infrared measurements by a helicopter-borne thermocamera over the geothermal areas of Unzen volcano, Japan. J. Volcanol. Geotherm. Res. 9 (1), 99-109. http://dx.doi.org/ 10.1016/0377-0273(81)90017-2.

Zlotnicki, J., Boudon, G., Le Mouël, J.-L., 1992. The volcanic activity of La Soufrière of Guadeloupe (Lesser Antilles): structural and tectonic implications. J. Volcanol. Geotherm. Res. 49 (1-2), 91-104. http://dx.doi.org/10.1016/0377-0273(92)90006-Y.

Zlotnicki, J., Feuillard, M., Hammouya, G., 1994. Water circulations on La Soufrière volcano inferred by self-potential surveys (Guadeloupe, Lesser Antilles). Renew of volcanic activity? J. Geomagn. Geoelectr. 46 (9), 797-813. 